\title{
The Capital Structure of Multinational COMPANIES UNDER TAX COMPETITION
}

\author{
PAOLO M. PANTEGHINI
}

\section{CESIFO WORKING PAPER NO. 1721 \\ CATEGORY 1: PUBLIC FinANCE \\ MAY 2006}

Presented at CESifo Area Conference on Public Sector Economics, April 2006

\footnotetext{
An electronic version of the paper may be downloaded

- from the SSRN website:

www.SSRN.com

- from the RePEc website:

Www.RePEC.org

- from the CESifo website:

www.CESifo-group.de
} 


\title{
The Capital Structure OF Multinational COMPANIES UNDER TAX COMPETITION
}

\begin{abstract}
This article studies the relationship between debt policies of multinational companies (MNCs) and governments' tax strategies. In the first part, it is shown that the ability to shift income from high- to low-tax countries affects MNCs' financial choices. In the second part we show how MNCs' financial decisions can affect the tax strategies of two governments competing to attract income.
\end{abstract}

JEL Code: G31, H25, H32.

Keywords: capital structure, country risk, default, multinationals, tax competition.

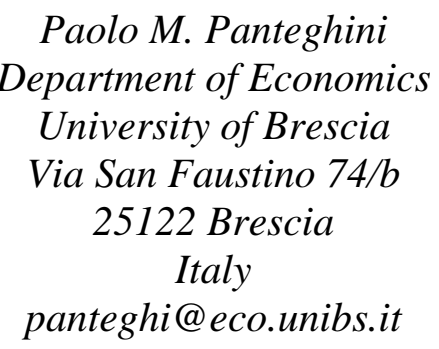

May 2, 2006

I wish to thank Roberto Casarin, Clemens Fuest, Francesco Menoncin, and Raffaele Miniaci for valuable comments and suggestions on a previous version of the paper. I am also grateful to Monika Bütler and other participants to the 2006 CESifo Area Conference on Public Sector Economics for helpful discussion and suggestions. 


\section{Introduction}

The literature on multinational companies (MNCs) has gathered interesting pieces of evidence regarding both financing decisions and the ability to shift income from high- to low-tax jurisdictions. ${ }^{1}$ It is well-known, indeed, that income can be shifted by means of debt policies, and that the amount of income shifted depends on tax rate differentials. ${ }^{2}$ Moreover we know that debt policies are affected not only by tax factors but also by other determinants, such as distress costs and risk. ${ }^{3}$

The aim of this article is twofold: we address both a positive and a normative point. The former regards the interactions between income shifting and debt strategies in a stochastic context. It is worth noting that so far the literature on income shifting has mainly focused on financial strategies in a deterministic context (see e.g. Altshuler and Grubert, 2003, and Mintz and Smart, 2004). To enrich the analysis we introduce business, default and policy risk, as well as default costs. In doing so we provide a theoretical framework which, by accounting for the above evidence, allows to better understand the effects of income shifting on the financing strategies of a representative MNC.

The latter (normative) issue regards tax competition. We study how governments' fiscal policies can be affected by MNCs' strategies. In particular we analyze the behavior of two governments which compete to attract income. We then show that financial choices may affect the equilibrium tax rates levied by the competing governments.

This article is related to two streams of literature. The first deals with firms' optimal capital structure. According to this approach, optimal leverage is reached when the marginal benefit of debt financing (which is due to the deductibility of interest expenses) equates its marginal cost (which is related to the expected cost of default). ${ }^{4}$ We thus analyze the effects of taxation on financial choices, and measure the impact of both default and policy risk on

\footnotetext{
${ }^{1}$ Income shifting activities are for instance dealt with by Altshuler and Grubert (2003), Graham and Tucker (2005), and Mintz (2000). Further evidence on the interactions between taxation and debt choices is provided by Mintz and Weichenrieder (2005).

${ }^{2}$ See e.g. Hines (1999), Mills and Newberry (2004) and Mintz and Smart (2004).

${ }^{3}$ Desai et al. (2004) show that political risk encourages MNCs to use greater debt. Fan et al. (2003) make a cross-country comparison supporting the idea that business risk discourages debt issues.

${ }^{4}$ For further details on this approach see e.g. Leland (1994).
} 
the optimal capital structure of a representative MNC. To show this we will introduce two well-known default conditions, which refer to protected debt, and unprotected debt financing, respectively. ${ }^{5}$

Under protected debt financing default may be triggered when the firms' asset value falls to the debt's value. Under unprotected debt financing the MNC has a higher degree of financial flexibility. If indeed there is a threat of default, the parent firm could decide to convert intra-firm debt into equity in order to prevent default. ${ }^{6}$ Therefore, unprotected debt financing implies that default timing is optimally chosen by the MNC. When the subsidiary's net cash flow is negative, the parent company can decide to inject further equity capital in order to meet the subsidiary's debt obligations and delay default. As long as it issues new capital and pays the interest rate it can thus exploit future recoveries in the firm's profitability. ${ }^{7}$

As pointed out by Leland (1994) both protected and unprotected debt are widely used. In particular, minimum net-worth requirements, implied by protected debt, are common in short-term debt financing, whereas long-term debt instruments are usually unprotected or only partially protected.

The second stream of research we refer to deals with tax competition. ${ }^{8}$ It is worth noting that most of this literature does not deal with risk. ${ }^{9}$ Moreover, as Wilson and Wildasin (2004, p.1084) point out, "analysis of the interaction between factor mobility, the structure of financial markets and institutions ... is still at an early stage". By merging the above streams we thus aim to provide a better understanding of possible interactions between MNCs' policies and governments' strategies. In particular, we show that the equilibrium tax rates of two competing governments depend on the default condition applied, namely on the characteristics of debt. We also prove that an increase in either the cost of default or the cost of income shifting raises tax rates. Moreover, we show that an increase in credibility, i.e. a lower risk of expropriation, allows governments to set higher tax rates. Finally, we find that

\footnotetext{
${ }^{5}$ For a detailed analysis of debt protection see e.g. Smith and Warner (1977).

${ }^{6}$ I wish to thank Clemens Fuest who raised this point when reading a previous version of this article.

${ }^{7}$ In this case, the MNC behaves as if it owned a put option, whose exercise leads to default.

${ }^{8}$ Recent evidence on tax competition is provided by Devereux et al. (2004).

${ }^{9}$ A few exceptions are Gordon and Varian (1989) and Lee (2004). See also Panteghini and Schjelderup (2006) who deal with MNCs' investment strategies and their interactions with governments' policies.
} 
both business and default risk reduce the MNC's propensity to borrow and lead to higher tax rates.

The structure of the article is as follows. Section 2 describes the model. Section 3 deals with the financing strategies of a representative MNC, that can shift income from one country to another. Section 4 uses a two-country model to investigate how MNCs' strategies can affect governments' policies. Section 5 summarises the main findings and derives policy implications.

\section{The model}

In this section we introduce a model describing the financial strategies of a representative MNC resident in country A, and owning a subsidiary located in country B. The subsidiary can borrow from a perfectly competitive credit sector, which is characterized by a given risk-free interest rate $r$, and by symmetric information. The following assumptions hold:

1. the parent company produces a given amount $\Psi_{A}$ of operating profits in its home country;

2. the EBIT (Earning Before Interest and Taxes) of the foreign subsidiary, defined as $\Pi_{B}(t)$, follows a geometric Brownian motion

$$
\frac{d \Pi_{B}(t)}{\Pi_{B}(t)}=\sigma d z_{B}(t), \text { with } \Pi_{B}(0) \geq 0,
$$

where $\sigma$ is the instantaneous standard deviation of $\frac{d \Pi_{B}(t)}{\Pi_{B}(t)}$, and $d z_{B}(t)$ is the increment of a Wiener process; ${ }^{10}$

3. at time 0 , the subsidiary borrows some resources and pays a constant coupon which cannot be renegotiated;

4. default occurs when the subsidiary does not meet its debt obligations;

5. the cost of default is proportional to the coupon received;

\footnotetext{
${ }^{10}$ The general form of the geometric Brownian motion is $d \Pi_{B}(t)=\mu \Pi_{B}(t) d t+$ $\sigma \Pi_{B}(t) d z_{B}$ where $\mu$ is the expected rate of growth. If shareholders are risk neutral in equilibrium we have $\mu=r-\delta$, where $r$ is the risk-free interest rate and $\delta$ is the convenience yield (see e.g. McDonald and Siegel, 1985). With no loss of generality, in (1) we set $\mu=r-\delta=0$.
} 
6. the MNC believes that there is some positive probability $\lambda d t$ that the foreign government expropriates its subsidiary during the short interval $d t$.

The above assumptions deserve some comments. Assumption 1 states that the operating profits of the parent company $\left(\Psi_{A}\right)$ are exogenously given, whereas, according to Assumption 2, the subsidiary's EBIT is stochastic. These two hypotheses allow us not only to analyze the effects of foreign business risk on the parent company in a tractable way, ${ }^{11}$ but also to account for the fact that MNCs are an important channel for the transmission of country-specific shocks. ${ }^{12}$

In line with Leland (1994), Assumption 3 entails that the MNC sets a coupon and then computes the market value of debt. In the absence of arbitrage, this is equivalent to first set, the value of debt and then, compute the effective interest rate under the non-arbitrage condition. For simplicity we also assume that debt cannot be renegotiated. ${ }^{13}$

Assumption 4 introduces the risk of default for the subsidiary. Given (1), it is assumed that if the subsidiary' EBIT falls to a given threshold value, the subsidiary is expropriated by the lender, and the parent company becomes a domestic firm with a gross cash flow equal to $\Psi_{A}$. As we pointed out in the introduction we will use the following alternative definitions of default. ${ }^{14}$

Definition 1 Under protected debt financing, default takes place when $\Pi_{B}$ falls to an exogenously given threshold point $\bar{\Pi}_{B}^{p}$.

Definition 2 Under unprotected debt financing, the threshold point $\bar{\Pi}_{B}^{u}$ is chosen optimally by shareholders at time 0.

According to Definition 1, default may be triggered when the subsidiary's payoff falls to the exogenously given threshold point $\bar{\Pi}_{B}^{p}$. The second definition regards unprotected debt. This condition implies that default timing

\footnotetext{
${ }^{11}$ If both $\Psi_{A}$ and $\Pi_{B}$ were stochastic, the MNC's overall pre-tax operating profit $\left(\Psi_{A}+\Pi_{B}\right)$ would not follow the Markov Properties. Thus we would fail to obtain a closed-form solution.

${ }^{12}$ As shown by Desai and Foley (2004), rates of return and investment rates of affiliates are highly correlated with the rates of return and investment of the affiliate's parent and other affiliates within the same group.

${ }^{13}$ For an analysis of debt renegotiation see e.g. Goldstein et al. (2001).

${ }^{14}$ For further details on default conditions see Smith and Warner (1977), and Leland (1994). For a study of corporate taxation under default risk see also Panteghini (2004, 2006).
} 
is optimally chosen by the MNC. When the subsidiary's net cash flow is negative, indeed the parent company can decide to inject equity and exploit future recoveries in the subsidiary's payoff.

In the event of default, the lender faces a sunk cost, which is proportional to the coupon paid (Assumption 5). It is worth noting that the quality of results does not change if we assume that the cost of default is proportional to the firm value, rather than to the debt value.

Finally, Assumption 6 describes the MNC's beliefs on the credibility of future government policy. In particular, it is assumed that the MNC fears that the foreign government may expropriate its subsidiary. Since such an expropriation is a sudden event, we model policy risk as a Poisson process, where $\lambda d t$ is the instantaneous a priori probability that expropriation occurs in the short interval $d t$.

Let us next introduce taxation. For simplicity we assume that the tax system is fully symmetric and follows the source principle. ${ }^{15}$ We also assume that the MNC can shift a percentage $\gamma_{A}$ of the coupon paid by the foreign subsidiary. However, shifting income by means of intra-firm borrowing and lending is costly. The cost of income shifting is due to two main factors: one is related to advising activities and the other is due anti-avoidance rules. On the one hand, shifting income usually requires the costly advice of tax and financial experts. On the other hand, countries aim to prevent taxavoiding practices by introducing ad hoc rules, such as thin capitalization and Controlled-Foreign-Company (CFC) rules. ${ }^{16}$

The cost function $\nu\left(\gamma_{A}\right)$ we use is convex in $\gamma_{A} \cdot{ }^{17}$ Defining $\tau_{A}$ and $\tau_{B}$ as the tax rate of country $\mathrm{A}$ and $\mathrm{B}$, respectively, we can write the overall profit function of the MNC as

$Y_{A}^{N}\left(\Pi_{B}(t)\right)=\left(1-\tau_{A}\right)\left[\Psi_{A}-\gamma_{A} C_{B}^{j}\right]+\left(1-\tau_{B}\right)\left[\Pi_{B}(t)-C_{B}^{j}+\gamma_{A} C_{B}^{j}\right]-\nu\left(\gamma_{A}\right) C_{B}^{j}$,

where $C_{B}^{j}$ is the coupon paid to the lender. The term $j=p, u$ stands for protected and unprotected, respectively. In line with Desai and Foley's (2004) empirical findings, the overall profit function (2) is affected by the transmis-

\footnotetext{
${ }^{15}$ Notice that the existence of deferral possibilities and limited credit rules leads to the application of the source principle (see e.g. Keen, 1993).

${ }^{16}$ For further details on this point see Fuest and Hemmelgarn (2005).

${ }^{17}$ In line with Panteghini and Schjelderup (2006) we assume that the cost of income shifting is non deductible. See also Haufler and Schjelderup (2000) for a discussion on this point.
} 
sion of country B's shock. Manipulating (2) one obtains

$$
Y_{A}^{N}\left(\Pi_{B}(t)\right)=\left(1-\tau_{A}\right) \Psi_{A}+\left(1-\tau_{B}\right) \Pi_{B}(t)-(1-\widetilde{\tau}) C_{B}^{j},
$$

where $\widetilde{\tau} \equiv \tau_{B}+\phi\left(\gamma_{A}\right)$ is the effective tax benefit arising from the deduction of the coupon. As can be seen, $\widetilde{\tau}$ accounts for the net benefit of income shifting, i.e. $\phi\left(\gamma_{A}\right) \equiv\left[\left(\tau_{A}-\tau_{B}\right) \gamma_{A}-\nu\left(\gamma_{A}\right)\right]$. A trade-off arises from debt financing. On the one hand, interest deductibility ensures a tax benefit. On the other hand, debt may cause default. Such a trade-off will then induce the MNC to choose the subsidiary's optimal leverage ratio. Since the tax benefit $\widetilde{\tau}$ depends on income reporting strategies, i.e. on $\phi\left(\gamma_{A}\right)$, it will then be straightforward to show that financial choices are affected by tax shifting activities.

With no loss of generality we assume that $\nu\left(\gamma_{A}\right)$ is a quadratic function, i.e.

$$
\nu\left(\gamma_{A}\right)=\frac{n}{2} \gamma_{A}^{2},
$$

where $n \geq 0$ measures how costly it is for the MNC to shift income from one country to the other. If thus $n$ goes to zero, the firm can shift profit at no cost. If, instead, $n$ goes to infinity, income shifting is too costly.

As we pointed out, the cost of income shifting is due to institutional determinants as well as to tax and financial advising activities. In particular, the introduction of thin capitalization and CFC devices, aiming to prevent tax avoiding activities, raises $n$. Moreover the decrease in the cost of tax sheltering operations, which is linked to the degradation of book and tax profits ${ }^{18}$ leads to a decrease in $n$. The MNC's income shifting problem is thus as follows

$$
\phi\left(\gamma_{A}^{*}\right) \equiv \max _{\gamma_{A}}\left[\left(\tau_{A}-\tau_{B}\right) \gamma_{A}-\nu\left(\gamma_{A}\right)\right]
$$

Solving (3) we obtain the optimal level of income shifting

$$
\gamma_{A}^{*}=\frac{\tau_{A}-\tau_{B}}{n} .
$$

As shown in (4), the optimal percentage of income shifted is reached when the marginal gain in terms of tax savings, here expressed by tax rate differential

\footnotetext{
${ }^{18}$ In particular, financial engineering has reduced the cost of recharacterizing profits to avoid taxation. On this point see e.g. Desai $(2003,2005)$.
} 
$\left(\tau_{B}-\tau_{A}\right)$, is equal to the marginal cost of income shifting. ${ }^{19}$ If therefore $\tau_{A}>\tau_{B}$ the firm shifts income from country A to country B and vice versa. ${ }^{20}$ Substituting (4) into (3) we have

$$
\phi\left(\gamma_{A}^{*}\right)=\frac{\left(\tau_{A}-\tau_{B}\right)^{2}}{2 n} .
$$

\section{The MNC's capital structure}

The framework so far obtained accounts for interesting characteristics of MNCs, such as the use of debt for tax-motivated income reporting strategies, under business, default and policy risk. In this section we show how these features may affect the financing strategies of the representative MNC. For simplicity, hereafter we will omit the time variable $t$.

In order to find the MNC's optimal capital structure, we must first compute the value function

$$
V_{A}^{j}\left(\Pi_{B}\right)=D_{A}^{j}\left(\Pi_{B}\right)+E_{A}^{j}\left(\Pi_{B}\right), \text { with } j=p, u,
$$

where $D_{A}^{j}\left(\Pi_{B}\right)$ and $E_{A}^{j}\left(\Pi_{B}\right)$ are the value of debt and equity, respectively.

Let us first calculate the value of debt, under the assumption that, before default, the lender is tax exempt. ${ }^{21}$ When, in the event of default, the lender becomes shareholder, however, it is subject to the source-based tax levied on the subsidiary. According to Assumption 5, moreover, we set the cost of default equal to $v C_{B}$, where the parameter $v>0$ measures the impact of default on the lender's profitability.

\footnotetext{
${ }^{19}$ The fact that statutory tax rates are a fairly important factor that influences income shifting decisions is well supported by empirical findings. On this point see e.g. Hines (1999), Desai et al. (2004), and Mills and Newberry (2004).

${ }^{20}$ In our model the optimal percentage of income shifting $\gamma_{A}^{*}$ is not state contingent. This symplifying assumption implies that the choice of $\gamma_{A}^{*}$ affects the MNC's financial decisions but does not depend on such decisions.

${ }^{21}$ It is well-known that effective tax rates on capital income are fairly low. With no loss of generality we thus assume that the lender's pre-default tax burden is nil.
} 


\subsection{The debt value}

Given the default threshold point $\bar{\Pi}_{B}^{j}$, the value of debt is thus equal to (see Appendix A)

$$
D_{A}^{j}\left(\Pi_{B}\right)= \begin{cases}\frac{\left(1-\tau_{B}\right) \bar{\Pi}_{B}^{j}}{r+\lambda} & \text { after default } \\ \frac{C_{B}^{j}}{r+\lambda}+\left[\frac{\left(1-\tau_{B}\right) \bar{\Pi}_{B}^{j}}{r+\lambda}-\frac{C_{B}^{j}}{r+\lambda}-v C_{B}^{j}\right]\left(\frac{\Pi_{B}}{\bar{\Pi}_{B}^{j}}\right)^{\beta_{2}} & \text { before default }\end{cases}
$$

where $\beta_{2}=\frac{1}{2}-\sqrt{\left(\frac{1}{2}\right)^{2}+\frac{2(r+\lambda)}{\sigma^{2}}}<0$. As shown in (7), the value of debt accounts for the risk of expropriation (i.e. parameter $\lambda$ ). In line with Dixit and Pindyck (1994), we account for this risk as follows: we regard the lender's claim as an infinitely-lived one, but we raise the discount rate from $r$ to $(r+\lambda)$.

Before default, $D_{A}^{j}\left(\Pi_{B}\right)$ consists of two terms. The first one, $\frac{C_{B}^{j}}{r+\lambda}$, is a perpetual rent computed with the augmented discount rate $(r+\lambda)$. The second term accounts for any future expected change in profitability caused by default. In particular, the term $\left(\frac{\Pi_{B}}{\bar{\Pi}_{B}^{j}}\right)^{\beta_{2}}$ measures the present value of 1 Euro contingent on the event default. After default, the lender becomes shareholders and the value of her claim is $\frac{\left(1-\tau_{B}\right) \bar{\Pi}_{B}^{j}}{r+\lambda}$, with $j=p, u$.

\subsection{The equity value}

Let us next compute the value of equity. According to Assumption 4, when default occurs the parent company loses its subsidiary and receives a net operating profit equal to $\left(1-\tau_{A}\right) \Psi_{A}$. Thus the value of equity is simply equal to the perpetual rent $\frac{\left(1-\tau_{A}\right) \Psi_{A}}{r} .{ }^{22}$ Before default, the MNC must account for the risk of expropriation of its subsidiary. As shown in Appendix B, therefore, we have

\footnotetext{
${ }^{22}$ Notice that, given the discount rate $r$, the $\mathrm{MNC}$ assumes that the risk of expropriation in its home country is null.
} 


$$
E_{A}^{j}\left(\Pi_{B}\right)= \begin{cases}\frac{\left(1-\tau_{A}\right) \Psi_{A}}{r} & \text { after default } \\ \frac{\left(1-\tau_{A}\right) \Psi_{A}}{r}+\frac{\left(1-\tau_{B}\right) \Pi_{B}-(1-\widetilde{\tau}) C_{B}^{j}}{r+\lambda}+f^{j}\left(\bar{\Pi}_{B}^{j}\right) & \text { before default }\end{cases}
$$

where $f^{p}\left(\bar{\Pi}_{B}^{p}\right)=0$ and $f^{u}\left(\bar{\Pi}_{B}^{u}\right)=\left(\frac{1}{1-\beta_{2}}\right)\left[\frac{(1-\widetilde{\tau}) C_{B}^{u}}{r+\lambda}\right]\left(\frac{\Pi_{B}}{\bar{\Pi}_{B}^{u}}\right)^{\beta_{2}}$.

The term $\frac{\left(1-\tau_{B}\right) \Pi_{B}-(1-\widetilde{\tau}) C_{B}^{j}}{r+\lambda}$ measures the net benefit arising from the ownership of the subsidiary. As can be seen, this term is equal to the present value of the net cash flow with discount rate $(r+\lambda)$. The term $f^{u}\left(\bar{\Pi}_{B}^{u}\right)$ measures the value of financial flexibility under unprotected debt financing. As we pointed out, the MNC has opportunity to inject equity (or, equivalently, convert intra-debt into equity) in order to delay default and exploit future tax avoidance benefits, as well as any recovery in the subsidiary's profitability.

We can now compute the default threshold points under protected and unprotected debt financing. According to Definition 1, protected debt financing means that the default threshold point $\bar{\Pi}_{B}^{p}$ is exogenously given. We assume that $\bar{\Pi}_{B}^{p}$ is such that the MNC's overall profit is nil, i.e. ${ }^{23}$

$$
Y_{A}^{N}\left(\bar{\Pi}_{B}^{p}\right)=\left(1-\tau_{A}\right) \Psi_{A}+\left(1-\tau_{B}\right) \bar{\Pi}_{B}^{p}-(1-\widetilde{\tau}) C_{B}^{j}=\left(1-\tau_{A}\right) \Psi_{A},
$$

thereby obtaining

$$
\bar{\Pi}_{B}^{p} \equiv \frac{(1-\widetilde{\tau})}{\left(1-\tau_{B}\right)} C_{B}^{p}
$$

Let us next compute the threshold value under unprotected debt financing. Following Leland (1994), $\bar{\Pi}_{B}^{u}$ is obtained by maximizing the value of equity, i.e.

$$
\max _{\bar{\Pi}_{B}^{u}} E_{A}^{u}\left(\Pi_{B}\right) .
$$

Substituting (8) into (10) we can compute the MNC's default trigger point (see Appendix B)

$$
\bar{\Pi}_{B}^{u}=\frac{\beta_{2}}{\beta_{2}-1} \frac{(1-\widetilde{\tau})}{\left(1-\tau_{B}\right)} C_{B}^{u} .
$$

As can be seen, the threshold points $\bar{\Pi}_{B}^{p}$ and $\bar{\Pi}_{B}^{u}$ are proportional to the coupon paid, and are instead independent of the current EBIT.

\footnotetext{
${ }^{23}$ The quality of results does not change if we assume a different threshold value.
} 
Comparing (9) with (11) it is straightforward to show that, coeteris paribus, the inequality $\bar{\Pi}_{B}^{u}<\bar{\Pi}_{B}^{p}$ holds. Under unprotected debt financing, the $\mathrm{MNC}$ can inject equity in order to meet the subsidiary's debt obligations. This means that, relative to the protected case, the MNC postpones default.

Moreover, it is easy to show that $E_{A}^{u}\left(\Pi_{B}\right)>E_{A}^{p}\left(\Pi_{B}\right)$. Such a difference is due to the fact that under unprotected debt financing, the MNC is endowed with a put option (i.e. the option to default). This makes the claim more valuable. $^{24}$

Let us analyze the effects on tax avoidance on the default threshold points. It is straightforward to show that whenever tax avoidance is allowed we have $\widetilde{\tau}>\tau_{B}$, and the inequality $\frac{1-\widetilde{\tau}}{1-\tau_{B}}<1$ thus holds. Given (9) and (11), therefore, we can write the following:

Lemma 1 Tax avoidance leads to a postponement of delay.

\subsection{The optimal coupon}

Substituting (7) and (8) into (6) we obtain the overall value of the MNC

$$
V_{A}^{j}\left(\Pi_{B}\right)=\frac{\left(1-\tau_{A}\right) \Psi_{A}}{r}+\frac{\left(1-\tau_{B}\right) \Pi_{B}+\widetilde{\tau} C_{B}^{j}}{r+\lambda}-\left(\frac{\widetilde{\tau}}{r+\lambda}+v\right) C_{B}^{j}\left(\frac{\Pi_{B}}{\bar{\Pi}_{B}^{j}}\right)^{\beta_{2}} .
$$

Using (12) we can now find the optimal coupon. As shown by Leland (1994), the optimal coupon is the solution of the following problem: ${ }^{25}$

$$
\max _{C_{B}^{j}} V_{A}^{j}\left(\Pi_{B}\right) .
$$

Solving (13) we obtain the optimal coupon (Appendix C)

\footnotetext{
${ }^{24}$ Given the inequality $E_{A}^{u}\left(\Pi_{B}\right)>E_{A}^{p}\left(\Pi_{B}\right)$ we might wonder why firms use protected debt as well. In fact unprotected debt would be preferable for shareholders. As pointed out by Leland (1994), protected debt may be preferred if agency costs are assumed. In particular protected debt may induce shareholders not to increase firm risk at the expense of the lender. However this point is beyond the scope of our article.

${ }^{25}$ The maximization of the MNC's overall value (including debt) implicitly rules out any agency conflict between shareholders and the lender. As pointed out in the previous footnote, strategic interactions, à la Myers (1977), are not deal with in this article.
} 


$$
\frac{C_{B}^{j}}{\Pi_{B}}=\left(m^{j}\right)^{-1} \frac{1-\tau_{B}}{1-\widetilde{\tau}}\left[\frac{1}{1-\beta_{2}} \frac{\widetilde{\tau}+(r+\lambda) v}{\widetilde{\tau}}\right]^{-\frac{1}{\beta_{2}}}
$$

with $m^{p}=1$ and $m^{u}=\frac{\beta_{2}}{\beta_{2}-1}$.

It is straightforward to show that $\left(\frac{C_{B}^{u}}{\Pi_{B}}\right)>\left(\frac{C_{B}^{p}}{\Pi_{B}}\right)$. Under unprotected debt financing the MNC can decide when to default. Its higher flexibility thus allows the MNC to raise leverage.

As shown in (14), $C_{B}^{j}$ is proportional to the current EBIT, $\Pi_{B}$, and is also affected by taxation. It is easy to ascertain that $\frac{\partial C_{B}^{j}}{\partial \tilde{\tau}}>0$. This means that the greater is the benefit arising from borrowing, i.e. $\widetilde{\tau}$, the higher the optimal coupon is. Not surprisingly an increase in $\widetilde{\tau}$ stimulates borrowing. On the other hand, we have $\frac{\partial C_{B}^{j}}{\partial v}<0$. This means that an increase in the sunk cost of default (i.e. in $v$ ) reduces the propensity to borrow. ${ }^{26}$

Let us next analyze the impact of income shifting on the capital structure. We can prove the following:

Lemma 2 If $\tau_{A} \neq \tau_{B}$ a decrease in $n$ raises the optimal coupon $C_{B}$.

Proof- See Appendix D.

The intuition behind Lemma 2 is straightforward: a reduction in the cost of income shifting encourages tax avoidance, and thus raises the tax benefit of debt financing. Such an increase stimulates the issue of debt and thus induces the MNC to pay a higher coupon.

Let us next analyze the effects of risk on the MNC's debt strategy. Given the above results we can write the following

Lemma 3 If $v$ is low enough, then $\frac{\partial \log \left(\frac{C_{B}^{j}}{\Pi_{B}}\right)}{\partial \sigma^{2}}>0$ and $\frac{\partial \log \left(\frac{C_{B}^{j}}{\Pi_{B}}\right)}{\partial \lambda}<0$.

Proof- See Appendix E.

The intuition behind these results is straightforward. If the cost of default is low enough, an increase in $\sigma$ reduces the ratio $\left(\frac{C_{B}^{j}}{\Pi_{B}}\right)$. In line with Leland (1994), indeed, an increase in volatility makes the costly event of default

\footnotetext{
${ }^{26}$ A detailed comparative statics analysis is provided by Leland (1994) and Goldstein et al. (2001).
} 
more likely and thus discourages debt financing. ${ }^{27}$ Moreover, an increase in $\lambda$ rises $\left(\frac{C_{B}^{j}}{\Pi_{B}}\right)$. This is due to the fact that a rise in $\lambda$ increases the discount rate $(r+\lambda)$. Thus the present value of 1 Euro contingent on the event of default is reduced. The decrease in the expected cost of default induces the MNC to borrow more resources (or, equivalently, to pay a higher coupon). As regards unprotected debt, the quality of results does not change. ${ }^{28} \mathrm{We}$ have thus provided a rationale for the positive effect of policy risk on debt financing, which has been found (but not explained) by Desai et al. (2004).

To have a better idea of the above effects we run a numerical simulation of $\left(\frac{C_{B}^{j}}{\Pi_{B}}\right)$ for different values of $\sigma^{2}$ and $\lambda$. As regards the tax rates, we follow Mills and Newberry (2004), and set the home corporate tax rate $\left(\tau_{A}\right)$ equal to the U.S. one, i.e. 0.35 , and the foreign one $\left(\tau_{B}\right)$ equal to the average statutory rate levied on foreign income, which is about 0.32 . We thus obtain $\tau_{A}-\tau_{B}=0.03$. Moreover, we follow Goldstein et al. (2001), and set $v=0.05$. It is worth noting that such a value is lower than those usually assumed in the relevant literature. ${ }^{29}$ Setting $r=0.045$ and focusing on protected debt we thus obtain the results depicted in Fig. 1.

Despite the use of a fairly low value of $v$, results are in line with Lemma 3: both an increase in $\sigma$ and a decrease in $\lambda$ raise the ratio $\left(\frac{C_{B}^{j}}{\Pi_{B}}\right)$. The quality of results does not change if we assume unprotected debt.

\footnotetext{
${ }^{27} \mathrm{As}$ we pointed out in the introduction this result is in line with the empirical findings of Fan et al. (2003).

${ }^{28}$ In order for the derivative $\frac{\partial \log \left(\frac{C_{B}^{j}}{\Pi_{B}}\right)}{\partial \beta_{2}}$ to be positive, we need a lower value of $v$.

${ }^{29}$ For instance Branch (2002) estimates a total default-related cost ranging between $12.7 \%$ and $20.5 \%$. However, Goldstein et al. (2001) criticize the existing literature in that it usually assumes too high costs.
} 


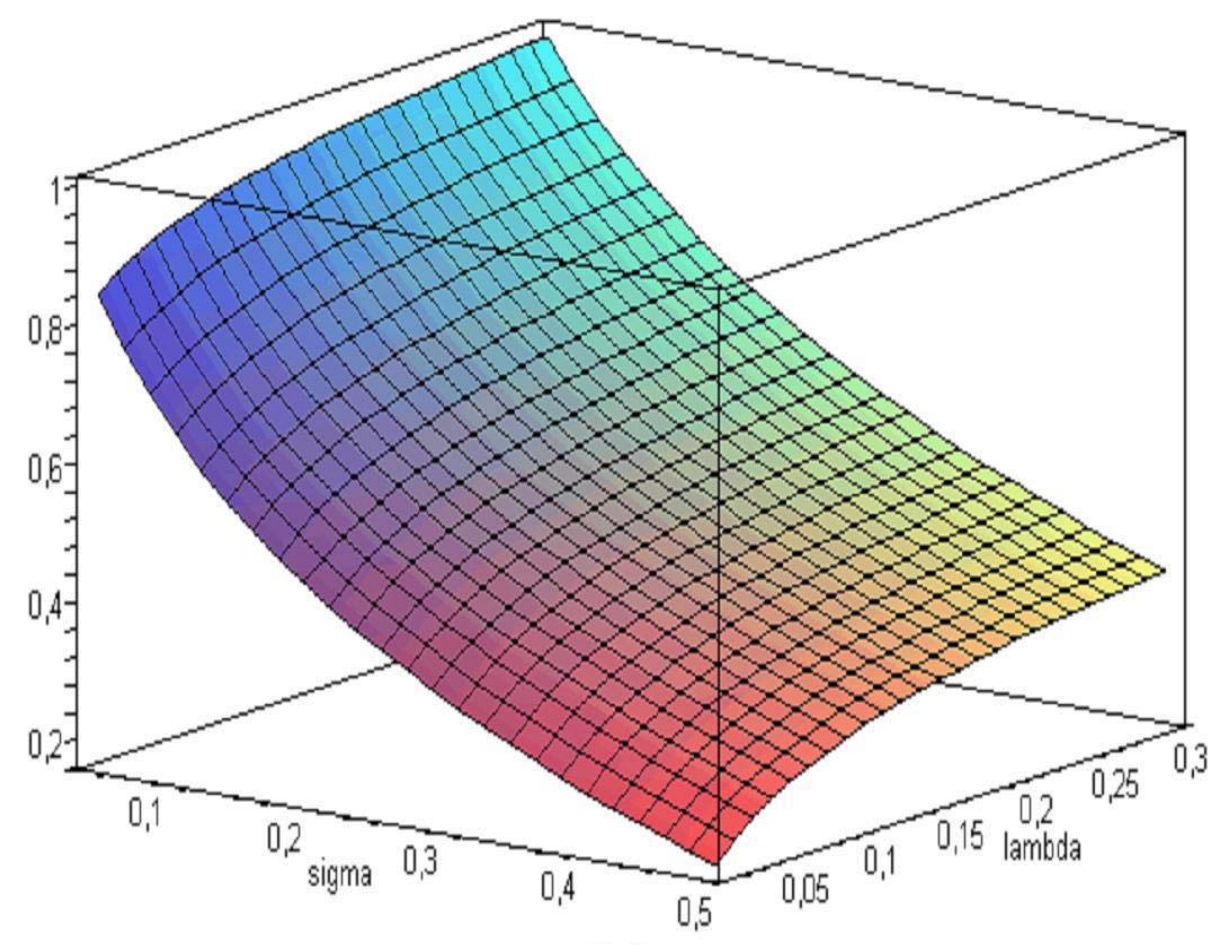

Figure 1: The effect of $\sigma$ and $\lambda$ on the ratio $\left(\frac{C_{B}^{p}}{\Pi_{B}}\right)$. 


\section{The competitive equilibrium}

In this section we model tax competition between two small open countries, called $A$ and $B$. We assume that, in each country, there exists a MNC which owns a foreign subsidiary and chooses its optimal capital structure. We thus use the MNC studied in the previous section, defined as MNC A, and then add a second MNC, named MNC B, with headquarter in country B, and a subsidiary operating in A. These MNCs face the same income shifting cost, i.e. $\nu\left(\gamma_{k}\right)$ with $k=A, B$.

Using the notation of Section 3, we define $\Psi_{B}$ as the firm's operating profit earned in country B (i.e. in MNC B's home country), and $C_{A}^{j}$ as the coupon paid to the lender. Moreover, $\Pi_{A}$ is the stochastic EBIT faced by the subsidiary, which is driven by the geometric Brownian motion $\frac{d \Pi_{A}}{\Pi_{A}}=\sigma d z_{A}$, with $\Pi_{A} \geq 0$. The overall profit earned by MNC B is therefore

$Y_{B}^{N}(t)=\left(1-\tau_{A}\right)\left[\Psi_{B}-\gamma_{B} C_{A}^{j}\right]+\left(1-\tau_{B}\right)\left[\Pi_{A}(t)-C_{A}^{j}+\gamma_{B} C_{A}^{j}\right]-\nu\left(\gamma_{B}\right) C_{A}^{j}$,

Given the above assumptions, we have two country-specific shocks: namely the shock faced by MNC A when investing in country B and the one faced by $\mathrm{MNC} \mathrm{B}$ when investing in country $\mathrm{A} .{ }^{30}$

Let us next compute the governments' objective functions, under the assumption that $100 \%$ of the MNC resident in the home country is held by domestic households. ${ }^{31}$ Moreover we assume that, despite MNCs' beliefs regarding policy risk, governments do not aim to expropriate foreign subsidiaries. Therefore the governments' objective functions do not embody the value of the foreign subsidiary, and are thus equal to the value of the resident MNC plus the present value of net tax revenues. The government A's objective function consists of five terms:

1. the value of equity of its resident MNC, i.e. ${ }^{32}$

$$
E_{A}^{j}\left(\Pi_{B}\right)=\frac{\left(1-\tau_{A}\right) \Psi_{A}}{r}+\frac{\left(1-\tau_{B}\right) \Pi_{B}-(1-\widetilde{\tau}) C_{B}^{j}}{r+\lambda}+f^{j}\left(\bar{\Pi}_{B}^{j}\right)
$$

\footnotetext{
${ }^{30}$ The quality of results does not change if we assume that these two shocks are correlated.

${ }^{31}$ Such a home-bias is well documented in the literature. However some recent articles have shown that it has declined over the last decade (see e.g. Sørensen et al., 2005).

${ }^{32} \mathrm{By}$ symmetry, the equity value of $\mathrm{MNC} \mathrm{B}$ is $E_{B}^{j}\left(\Pi_{A}\right)=\frac{\left(1-\tau_{B}\right) \Psi_{B}}{r}+$ $\frac{\left(1-\tau_{A}\right) \Pi_{B}-\left(1-\tau^{\prime}\right) C_{A}^{j}}{r}+f^{j}\left(\bar{\Pi}_{A}^{j}\right)$ with $\tau^{\prime} \equiv \tau_{A}+\phi\left(\gamma_{B}\right)$.
} 
2. the present value of tax revenues gathered from the resident MNC, which is equal to the perpetual rent $\frac{\tau_{A} \Psi_{A}}{r}$;

3. the present value of taxes paid by the foreign subsidiary: since taxes are paid irrespective of the firm's ownership, they are not contingent on the event of default and are thus equal to a perpetual flow; given the initial income produced by the foreign subsidiary $\Pi_{A}$, the present value of tax revenues is $\frac{\tau_{A} \Pi_{A}}{r}$;

4. the net loss of revenues caused by income shifting from the parent company, placed in A, and its subsidiary operating in B $\left(-\tau_{A} \gamma_{A}^{*} C_{B}^{j}\right)$ : as shown in Appendix F, its present value is

$$
N B_{B}^{j}\left(\Pi_{B}\right)=-\tau_{A} \gamma_{A} \frac{C_{B}^{j}}{r}\left[1-\left(\frac{\Pi_{B}}{\bar{\Pi}_{B}^{j}}\right)^{\beta_{2}}\right] ;
$$

5. the net loss of revenues due to income shifting from the parent company placed in B and its subsidiary operating in A, $\left(\tau_{A} \gamma_{B}^{*} C_{A}^{j}\right)$; the present value of this net flow is (see Appendix F)

$$
N B_{A}^{j}\left(\Pi_{A}\right)=\tau_{A} \gamma_{B} \frac{C_{A}^{j}}{r}\left[1-\left(\frac{\Pi_{A}}{\bar{\Pi}_{A}^{j}}\right)^{\beta_{2}}\right] .
$$

As can be seen, both (17) and (18) are conditional on the event of default. This is due to the fact that, whenever default takes place, debt turns into equity. Since the lender becomes shareholder, any tax benefit due to debt financing vanishes.

Adding the above terms, we obtain the government A's objective function $^{33}$

$$
\begin{gathered}
W_{A}^{j}=\frac{\Psi_{A}}{r}+\frac{\left(1-\tau_{B}\right) \Pi_{B}-(1-\widetilde{\tau}) C_{B}^{j}}{r+\lambda}+f^{j}\left(\bar{\Pi}_{B}^{j}\right)+ \\
-\tau_{A} \gamma_{A}^{*} \frac{C_{B}^{j}}{r}\left[1-\left(\frac{\Pi_{B}}{\bar{\Pi}_{B}^{j}}\right)^{\beta_{2}}\right]+\tau_{A} \gamma_{B}^{*} \frac{C_{A}^{j}}{r}\left[1-\left(\frac{\Pi_{A}}{\overline{\bar{\Pi}}_{A}^{j}}\right)^{\beta_{2}}\right]+\tau_{A} \frac{\Pi_{A}}{r} \text { with } j=p, u .
\end{gathered}
$$

\footnotetext{
${ }^{33}$ Notice that the governments do not account for the costs of profit shifting.
} 
Following the same procedure we also obtain the government B's objective function. ${ }^{34}$

Each government maximizes the welfare function,

$$
\max _{\tau_{k}} W_{k}^{j} \quad k=A, B .
$$

The maximization of (20) is part of a sequential game, where at stage 1 the governments set the tax rates, and at stage 2 the two MNCs will decide both their debt-equity ratio and the percentage of income shifting. Solving (20) we can prove the following:

Proposition 1 If $n$ is low enough, a unique symmetric Nash equilibrium tax rate $\tau^{*} \epsilon(0,1]$ exists. The equilibrium tax rate under protected debt financing is higher than that obtained under unprotected debt financing.

\section{Proof See Appendix G.}

The intuition behind Proposition 1 is straightforward. The equilibrium tax rate is $\tau^{*} \epsilon(0,1]$ on condition that $n$ is low enough, i.e. income shifting is profitable enough.

The effect of default conditions on the equilibrium tax rates can be explained as follows. As we pointed out in Section 3, we have $C_{B}^{u}>C_{B}^{p}$. Since under unprotected debt financing the firm's leverage is higher, for any given percentage of income shifted $\gamma_{k}^{*}$, tax avoidance ensures a greater benefit. Relative to the protected-debt case, therefore, the governments are thus obliged to decrease tax rates in order to reduce such a tax benefit. As a consequence, the equilibrium tax rate under unprotected debt financing is lower.

Proposition 1 is obtained by assuming that the objective function does not account for all the firm's value but only for equity value. However, it is easy to prove the following:

Corollary 1 The equilibrium tax rate is unchanged if the objective function also accounts for the value of debt.

\footnotetext{
${ }^{34}$ Using the same notation we obtain government B's welfare function:

$$
\begin{gathered}
W_{B}^{j}=\frac{\Psi_{B}}{r}++\frac{\left(1-\tau_{A}\right) \Pi_{A}-\left(1-\tau^{\prime}\right) C_{A}^{j}}{r}+f^{j}\left(\bar{\Pi}_{A}^{j}\right)+ \\
-\tau_{B} \gamma_{B}^{*} \frac{C_{A}^{j}}{r}\left[1-\left(\frac{\Pi_{A}}{\overline{\bar{\Pi}}_{A}^{j}}\right)^{\beta_{2}}\right]+\tau_{B} \gamma_{A}^{*} \frac{C_{B}^{j}}{r}\left[1-\left(\frac{\Pi_{B}}{\overline{\bar{\Pi}}_{B}^{j}}\right)^{\beta_{2}}\right]+\tau_{B} \frac{\Pi_{B}}{r} .
\end{gathered}
$$
}


Proof See Appendix H.

Corollary 1 shows that the result of Proposition 1 is unaffected by the change in the governments' objective functions. The intuition behind Corollary 1 is straightforward: as the credit market is perfectly competitive, all profits accrue to shareholders. Therefore adding the value of debt to the objective function does not increase the relevant tax base. The equilibrium tax rate is thus unchanged.

Let us next provide some comparative statics regarding $\tau^{*}$. We first analyze the impact of the default and the income shifting costs. We can prove the following:

Proposition 2 An increase in either the cost of default (i.e. in $v$ ) or the cost of shifting income (i.e. $n$ ) causes an increase in $\tau^{*}$.

Proof See Appendix I.

As shown in Proposition 2 both the distress and the income shifting cost have a positive impact on the equilibrium tax rates. An increase in $v$ raises the expected cost of default and thus discourages the use of debt. Coeteris paribus, a rise in $v$ reduces the optimal coupon and, given $\gamma_{k}^{*}$, the amount of income shifted from one country to the other. By discouraging income shifting, the increase in $v$ allows the competing governments to reach a higher equilibrium tax rate. This result has an interesting implication: both default procedures and debtors' protection rights (à la La Porta et al., 1997) can affect governments' fiscal strategies.

A similar reasoning holds for $n$. An increase in $n$ makes income shifting more costly: this allows the governments to set a higher $\tau^{*}$. This result has an interesting policy implication: as long as governments can affect the value of $n$, e.g. by means of more stringent anti-avoidance rules (such as thin capitalization and CFC rules), they can set a higher tax rate. This helps to explain the widespread introduction of these devices throughout the world. On the other hand, both the diffusion of sophisticated financial engineering activities and the decrease in tax consulting expenses may cause a reduction in $n$, and therefore lead to a decrease in $\tau^{*}$.

Let us next analyze the impact of $\sigma$ and $\lambda$ on the equilibrium tax rate. Like in Fig. 1 we focus on the protected-debt case. Using the same parameter values of the case depicted in Fig. 1 (i.e. $v=0.05, r=0.045, n=0.5$ ) we show that an increase in $\lambda$ leads to a decrease in the equilibrium tax rate. 


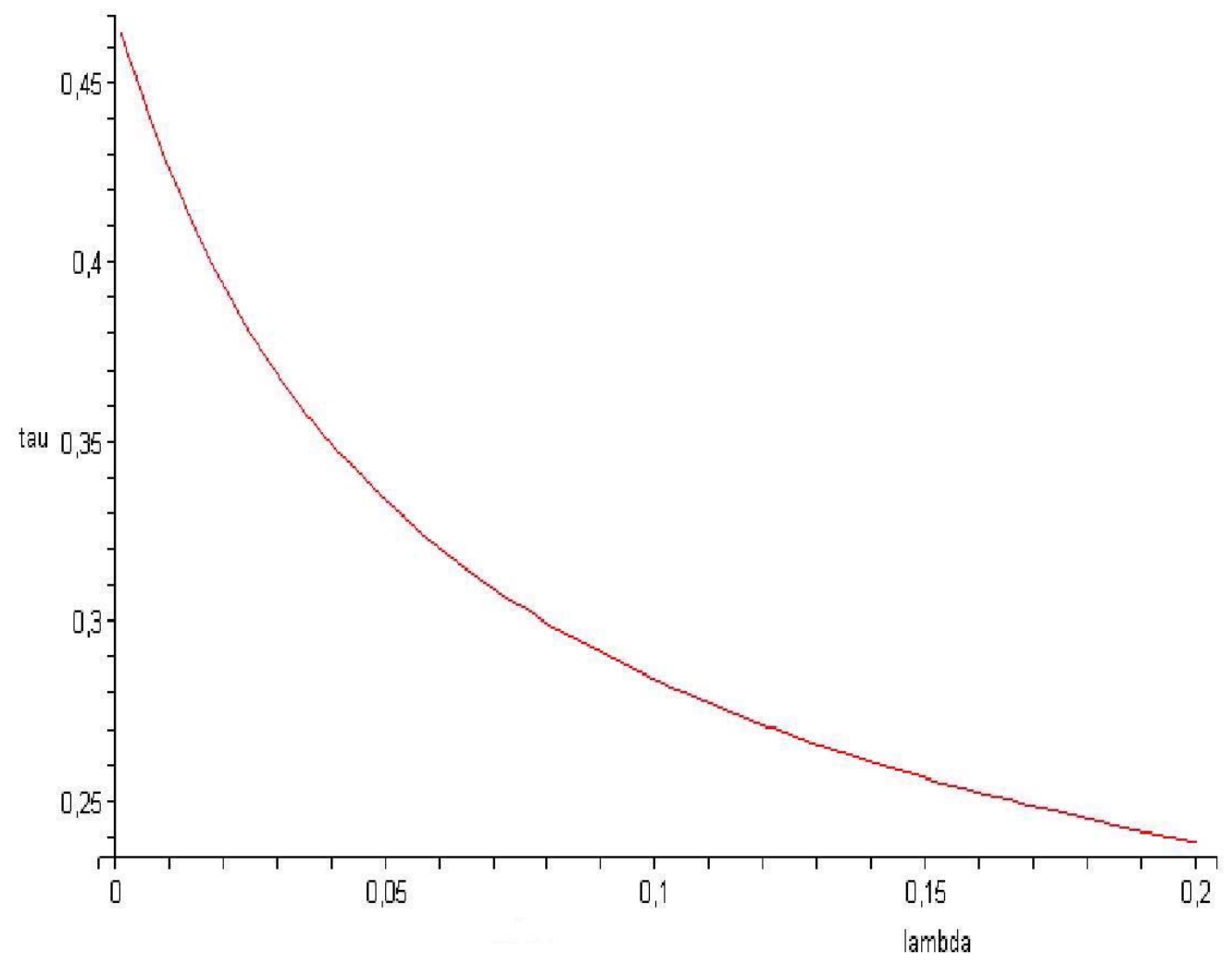

Figure 2: The effect of $\lambda$ on the equilibrium tax rate $\tau^{*}$.

The intuition behind this result is as follows: an increase in $\lambda$ stimulates borrowing, and thus raises the ratio $\left(\frac{C_{k}^{p}}{\Pi_{k}}\right)$, with $k=A, B$. Given the optimal percentage $\gamma_{k}^{*}$, therefore, a greater amount of income can be shifted. In order to offset the increase in income shifting opportunities, governments are thus induced to set lower tax rates.

This result has an interesting policy implication: an increase in credibility, i.e. a lower value of $\lambda$, allows governments to set higher tax rates. In this model we have used an one-shot game and assumed the absence of any debt renegotiation. If we enriched the framework by assuming a repeated game between governments and by allowing MNCs to renegotiate debt, we then would expect a positive relationship between reputation and the level of tax 


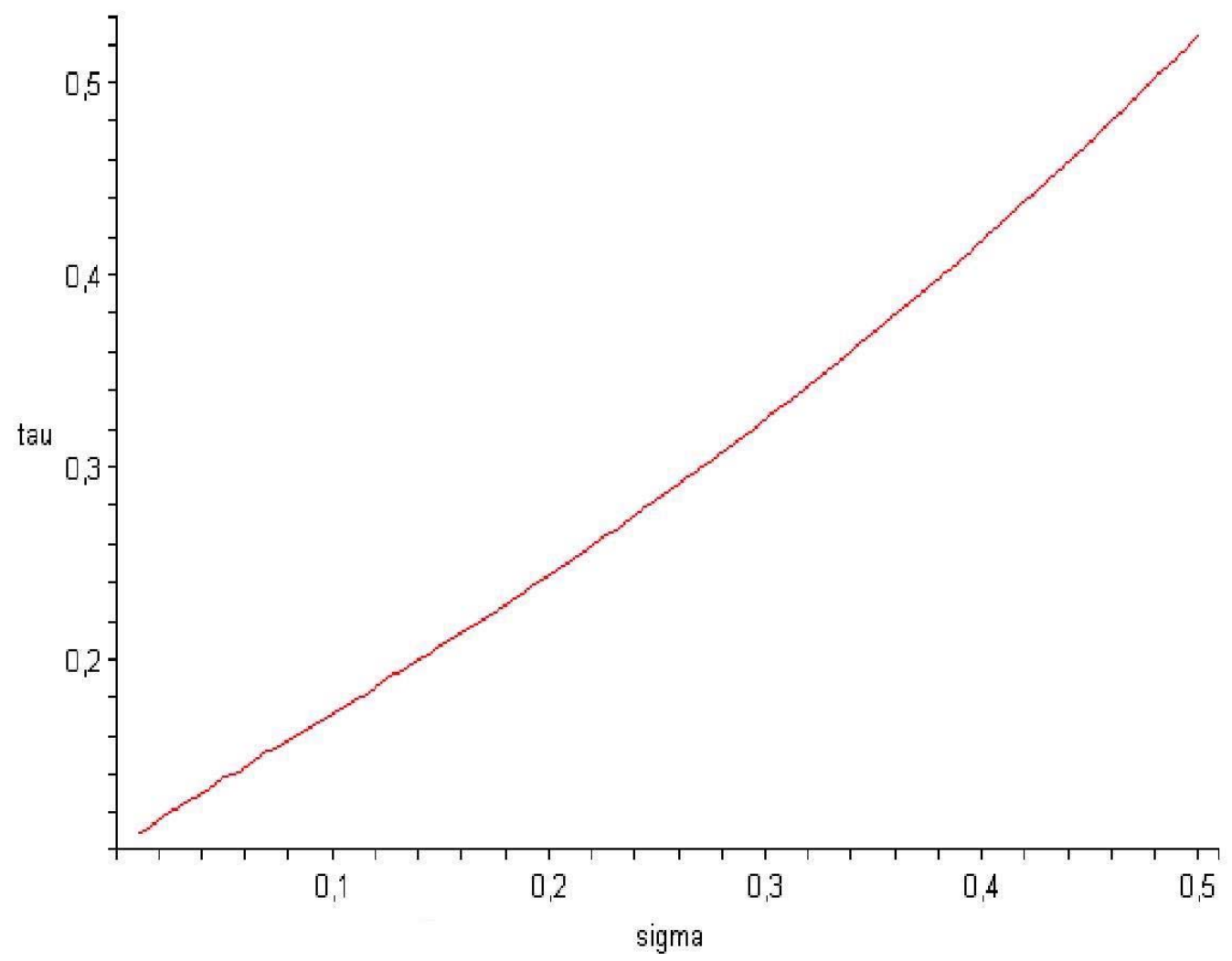

Figure 3: The effect of $\sigma$ on the equilibrium tax rate $\tau^{*}$.

rates. ${ }^{35}$

As shown in the previous Section, an increase in $\sigma$ discourages borrowing, and thus reduces the ratio $\left(\frac{C_{k}^{j}}{\Pi_{k}}\right)$. Coeteris paribus, therefore, income shifting is discouraged, and the governments can set higher tax rates (see Fig. 3). The quality of results does not change if we focus on unprotected debt financing.

Let us finally compare the last result with Panteghini and Schjelderup (2006), who show that an increase in volatility discourages FDIs and thus reduces the overall number of multinational firms. In their case, the policy

\footnotetext{
${ }^{35}$ This point has some similarities with Cherian and Perotti (2001), who show that a gradual increase in reputation allows governments to attract a greater amount of FDIs.
} 
response is therefore to lower the tax rate in order to alleviate the negative impact of increased volatility. In this model, however, we analyze MNCs' strategies when FDI has already been undertaken and income can be shifted by means of debt financing. This explains the different results obtained.

\section{Concluding remarks and policy implications}

In this article we have studied the interactions between financial policies and income shifting activities of MNCs in a stochastic environment. In the first part we have shown that income shifting both 1) raises the tax benefit of debt financing, thereby stimulating debt financing, and 2) delays default.

In the second part of the article we have analyzed the impact of MNCs' strategies on the behavior of two competing governments. In line with Wilson and Wildasin's (2004), we have studied how the structure of financial markets and institutions may matter in terms of fiscal policies. We have therefore shown that the characteristics of debt financing can affect the governments' strategies. In particular the equilibrium tax rate is lower under unprotected debt financing than under protected debt financing.

Moreover, we have found that an increase in either the cost of default or the cost of income shifting raises the equilibrium tax rate. These results have some interesting policy implications. First of all, the cost of default may affect governments' tax strategies. In particular, both default procedures and debtors' protection rights are expected to affect governments' fiscal strategies. Also, more stringent anti-avoidance devices, such as thin capitalization and CFC rules, allow governments to set higher tax rates.

Finally, we have shown that risk has an ambiguous impact on governments' strategies. On the one hand, policy risk (related to MNCs' beliefs that governments may expropriate foreign activities) reduces the equilibrium tax rate. On the other hand, an increase in both business and default risk leads to higher tax rates.

There are at least two topics that still need to be looked at. First of all, here we have assumed that tax rates are the only policy tool in the hand of the two competing governments. A natural extension of the model would then be the introduction of a second policy tool regarding the tax base. Secondly, this article proposes some testable hypotheses regarding the interactions between MNCs' activities and governments' policies. These findings are left for future empirical investigation. 


\section{A Derivation of (7)}

Using dynamic programming, debt can be written as

$D_{A}^{j}\left(\Pi_{B}\right)= \begin{cases}\left(1-\tau_{B}\right) \Pi_{B} d t+(1-\lambda d t) e^{-r d t} \xi\left[D_{A}^{j}\left(\Pi_{B}+d \Pi_{B}\right)\right] & \text { after default, } \\ C_{B}^{j} d t+(1-\lambda d t) e^{-r d t} \xi\left[D_{A}^{j}\left(\Pi_{B}+d \Pi_{B}\right)\right] & \text { before default, }\end{cases}$

where $\xi[$.$] is the expectation operator. Function (21) can be rewritten as$

$D_{A}^{j}\left(\Pi_{B}\right)= \begin{cases}\left(1-\tau_{B}\right) \Pi_{B} d t+(1-\lambda d t)(1-r d t) \xi\left[D_{A}^{j}\left(\Pi_{B}+d \Pi_{B}\right)\right] & \text { after default } \\ C_{B}^{j} d t+(1-\lambda d t)(1-r d t) \xi\left[D_{A}^{j}\left(\Pi_{B}+d \Pi_{B}\right)\right] & \text { before default. }\end{cases}$

Applying Itô's Lemma to (22), one obtains

$$
(r+\lambda) r D_{A}^{j}\left(\Pi_{B}\right)=L+\frac{\sigma^{2}}{2} \Pi_{B}^{2} D_{A_{\Pi_{B} \Pi_{B}}^{j}}\left(\Pi_{B}\right),
$$

where $L=\left(1-\tau_{B}\right) \Pi_{B}, C_{B}^{j}$, and $D_{A_{\Pi_{B} \Pi_{B}}^{j}}\left(\Pi_{B}\right)=\frac{\partial^{2} D_{A}^{j}\left(\Pi_{B}\right)}{\partial \Pi_{B}^{2}}$. The general closed-form solution of function (23) is

$$
D_{A}^{j}\left(\Pi_{B}\right)= \begin{cases}\frac{\left(1-\tau_{B}\right) \bar{\Pi}_{B}^{j}}{r+\lambda}+\sum_{i=1}^{2} B_{i}^{j} \Pi_{B}^{\beta_{i}} & \text { after default, } \\ \frac{C_{B}^{j}}{r+\lambda}+\sum_{i=1}^{2} D_{i}^{j} \Pi_{B}^{\beta_{i}} & \text { before default, }\end{cases}
$$

where $\beta_{1}$ and $\beta_{2}$ are, respectively, the positive and negative roots of the characteristic equation $\frac{\sigma^{2}}{2} \beta(\beta-1)-(r+\lambda)=0 .{ }^{36}$

To compute $B_{i}^{j}$ and $D_{i}^{j}$ for $i=1,2$, we introduce three boundary conditions. First of all we assume that whenever $\Pi_{B}$ goes to zero the lender's claim is nil, namely condition $D_{A}^{j}(0)=0$ holds. This implies that $B_{2}^{j}=0$. Secondly, we assume that financial bubbles do not exist. This means that $B_{1}^{j}=D_{1}^{j}=0 .{ }^{37}$ Thirdly, we must consider that at point $\Pi_{B}=\bar{\Pi}_{B}^{j}$, the

\footnotetext{
${ }^{36}$ These roots are $\beta_{1}=\frac{1}{2}+\sqrt{\left(\frac{1}{2}\right)^{2}+\frac{2(r+\lambda)}{\sigma^{2}}}>1$, and $\beta_{2}=\frac{1}{2}-\sqrt{\left(\frac{1}{2}\right)^{2}+\frac{2(r+\lambda)}{\sigma^{2}}}<0$.

${ }^{37}$ For further details on these boundary conditions see e.g. Dixit and Pindyck (1994).
} 
pre-default value of debt must be equal to the post-default one, net of the default cost. Using the two branches of (24) we thus obtain

$$
\frac{\left(1-\tau_{B}\right) \bar{\Pi}_{B}^{j}}{r+\lambda}-v C_{B}^{j}=\frac{C_{B}^{j}}{r+\lambda}+D_{2}^{j} \bar{\Pi}_{B}^{\beta_{2}} .
$$

Solving for $D_{2}^{j}$ yields

$$
D_{2}^{j}=\left[\frac{\left(1-\tau_{B}\right) \bar{\Pi}_{B}^{j}-C_{B}^{j}}{r+\lambda}-v C_{B}^{j}\right] \bar{\Pi}_{B}^{j^{-\beta_{2}}} .
$$

Given the above results it is straightforward to obtain (7).

\section{B Derivation of (8) and (11)}

To derive the value of equity we must remember that default causes an expropriation of the subsidiary. This means that whenever we have $\Pi_{B}=\bar{\Pi}_{B}^{j}$, the value of equity reduces to

$$
E_{A}^{j}\left(\bar{\Pi}_{B}^{j}\right)=\frac{\left(1-\tau_{A}\right) \Psi_{A}}{r},
$$

that is the fair value of the parent company when operating as a domestic firm.

Applying dynamic programming we next write the added value due to the ownership of a foreign subsidiary. Given the additional after-tax cash flow due to holding the subsidiary, i.e. $\left[Y_{A}^{N}\left(\Pi_{B}\right)-\left(1-\tau_{A}\right) \Psi_{A}\right]$, the added value is equal to

$S_{A}^{j}\left(\Pi_{B}\right)=\left\{\begin{array}{l}0 \\ {\left[Y_{A}^{N}\left(\Pi_{B}\right)-\left(1-\tau_{A}\right) \Psi_{A}\right] d t+(1-\lambda d t) e^{-r d t} \xi\left[E\left(\Pi_{B}+d \Pi_{B}\right)\right]}\end{array}\right.$

after default, before default.

As can be seen (26) embodies the net benefit arising from income shifting, and accounts for the risk of expropriation (i.e. the MNC's fear that the government expropriates its subsidiary). Using Itô's Lemma, eliminating all the terms multiplied by $(d t)^{2}$ and dividing by $d t$, we can rewrite (26) as

$$
(r+\lambda) S_{A}^{j}\left(\Pi_{B}\right)=\left[\left(1-\tau_{B}\right) \Pi_{B}-(1-\widetilde{\tau}) C_{B}^{j}\right]+\frac{\sigma^{2}}{2} \Pi_{B}^{2} S_{A_{\Pi_{B} \Pi_{B}}^{j}}\left(\Pi_{B}\right),
$$


where $S_{A_{\Pi_{B} \Pi_{B}}^{j}}\left(\Pi_{B}\right)=\frac{\partial^{2} S_{A}^{j}\left(\Pi_{B}\right)}{\partial \Pi_{B}^{2}}$. Solving (27) we have

$$
S_{A}^{j}\left(\Pi_{B}\right)= \begin{cases}0 & \text { after default } \\ \frac{\left(1-\tau_{B}\right) \Pi_{B}-(1-\widetilde{\tau}) C_{B}^{j}}{r+\lambda}+\sum_{i=1}^{2} A_{i}^{j} \Pi_{B}^{\beta_{i}} & \text { before default. }\end{cases}
$$

Let us next compute $A_{i}^{j}$ with $i=1,2$. In the absence of financial bubbles, we have $A_{1}^{j}=0$ for $j=p, u$. Moreover to compute $A_{2}^{j}$ we let the two branches of (28) meet at point $\Pi_{B}=\bar{\Pi}_{B}^{j}$ thereby obtaining

$$
S_{A}^{j}\left(\bar{\Pi}_{B}^{j}\right)=\frac{\left(1-\tau_{B}\right) \bar{\Pi}_{B}^{j}-(1-\widetilde{\tau}) C_{B}^{j}}{r+\lambda}+A_{2}^{j} \bar{\Pi}_{B}^{j^{\beta_{2}}}=0 .
$$

Solving for $A_{2}^{j}$ thus yields

$$
A_{2}^{j}=-\frac{\left(1-\tau_{B}\right) \bar{\Pi}_{B}^{j}-(1-\widetilde{\tau}) C_{B}^{j}}{r} \cdot \bar{\Pi}_{B}^{j-\beta_{2}}
$$

The pre-default value of equity is thus equal to

$$
\begin{gathered}
E_{A}^{j}\left(\Pi_{B}\right)=\frac{\left(1-\tau_{A}\right) \Psi_{A}}{r}+S_{A}^{j}\left(\Pi_{B}\right)= \\
=\frac{\left(1-\tau_{A}\right) \Psi_{A}}{r}+\frac{\left(1-\tau_{B}\right) \Pi_{B}-(1-\widetilde{\tau}) C_{B}^{j}}{r+\lambda}-\left[\frac{\left(1-\tau_{B}\right) \bar{\Pi}_{B}^{j}-(1-\widetilde{\tau}) C_{B}^{j}}{r+\lambda}\right]\left(\frac{\Pi}{\bar{\Pi}_{B}^{j}}\right)^{\beta_{2}},
\end{gathered}
$$

with $j=p, u$.

\section{B.1 Equity value under protected debt}

Recall that under full debt protection, we have $\bar{\Pi}_{B}^{p}=\frac{1-\widetilde{\tau}}{1-\tau_{B}} C_{B}^{j}$. In this case we have therefore $A_{2}^{p}=0$, and the value of equity reduces to

$$
E_{A}^{p}\left(\Pi_{B}\right)=\frac{\left(1-\tau_{A}\right) \Psi_{A}}{r}+\frac{\left(1-\tau_{B}\right) \Pi_{B}-(1-\widetilde{\tau}) C_{B}^{j}}{r+\lambda} .
$$

\section{B.2 Equity value under unprotected debt}

Under unprotected debt, instead, the MNC must solve (10). Using (29) one obtains the following f.o.c. 
$\frac{\partial E_{A}^{u}\left(\Pi_{B}\right)}{\partial \bar{\Pi}_{B}^{u}}=-\frac{\left(1-\tau_{B}\right)}{r+\lambda}\left(\frac{\Pi_{B}}{\bar{\Pi}_{B}^{u}}\right)^{\beta_{2}}+\beta_{2}\left(\frac{\left(1-\tau_{B}\right) \bar{\Pi}_{B}^{u}-(1-\widetilde{\tau}) C_{B}^{u}}{r+\lambda}\right)\left(\frac{\Pi}{\bar{\Pi}_{B}^{u}}\right)^{\beta_{2}} \bar{\Pi}_{B}^{u^{-1}}=0$

Solving for $\bar{\Pi}_{B}^{u}$ thus yields (11), i.e. $\bar{\Pi}_{B}^{u}=\frac{\beta_{2}}{\beta_{2}-1} \frac{(1-\widetilde{\tau})}{\left(1-\tau_{B}\right)} C_{B}^{u}$. Substituting (11) into (29) yields

$$
E_{A}^{u}\left(\Pi_{B}\right)=\frac{\left(1-\tau_{A}\right) \Psi_{A}}{r}+\frac{\left(1-\tau_{B}\right) \Pi_{B}-(1-\widetilde{\tau}) C_{B}^{u}}{r+\lambda}+\left(\frac{1}{1-\beta_{2}}\right)\left[\frac{(1-\widetilde{\tau}) C_{B}^{u}}{r+\lambda}\right]\left(\frac{\Pi_{B}}{\bar{\Pi}_{B}^{u}}\right)^{\beta_{2}}
$$

Finally, using (30) and (31) one easily obtains (8).

\section{The optimal coupon}

Let us solve problem (13). Using (12) and differentiating with respect to $C_{B}^{j}$, one easily obtains the f.o.c.

$$
\frac{\partial V_{A}^{j}\left(\Pi_{B}\right)}{\partial C_{B}^{j}}=\frac{\widetilde{\tau}}{r+\lambda}-\left(\frac{\widetilde{\tau}}{r+\lambda}+v\right)\left(\frac{\Pi_{B}}{\bar{\Pi}_{B}^{j}}\right)^{\beta_{2}}+\beta_{2}\left(\frac{\widetilde{\tau}}{r+\lambda}+v\right)\left(\frac{\Pi_{B}}{\bar{\Pi}_{B}^{j}}\right)^{\beta_{2}} \frac{C_{B}^{j}}{\bar{\Pi}_{B}^{j}} \frac{\partial \bar{\Pi}_{B}^{j}}{\partial C_{B}^{j}}=0
$$

with $\frac{C_{B}^{j}}{\bar{\Pi}_{B}^{j}} \frac{\partial \bar{\Pi}_{B}^{j}}{\partial C_{B}^{j}}=1$. Manipulating (32) yields

$$
\left(\frac{\Pi_{B}}{\bar{\Pi}_{B}^{j}}\right)^{\beta_{2}}=\frac{1}{1-\beta_{2}} \frac{\widetilde{\tau}+(r+\lambda) v}{\widetilde{\tau}+(r)}
$$

Substituting (9) and (11) into (33) yields (14).

\section{Proof of Lemma 2}

To prove Lemma 1, let us apply a log-transform to (14)

$$
\begin{gathered}
\log \left(\frac{C_{B}^{j}}{\Pi_{B}}\right)=-\log m^{j}+\log \left(1-\tau_{B}\right)-\log (1-\widetilde{\tau}) \\
-\frac{1}{\beta_{2}} \log \frac{1}{1-\beta_{2}}-\frac{1}{\beta_{2}} \log \left[\frac{\widetilde{\tau}}{\widetilde{\tau}+(r+\lambda) v}\right] .
\end{gathered}
$$


Differentiating (34) with respect to $\widetilde{\tau}$ yields

$$
\frac{\partial \log \left(\frac{C_{B}^{j}}{\Pi_{B}}\right)}{\partial \widetilde{\tau}}=\frac{1}{1-\widetilde{\tau}}-\frac{1}{\beta_{2}} \frac{(r+\lambda) v}{[\widetilde{\tau}+(r+\lambda) v] \widetilde{\tau}}>0
$$

Given $\frac{\partial \widetilde{\tau}}{\partial \phi\left(\gamma_{A}^{*}\right)}=1$ and $\frac{\partial \phi\left(\gamma_{A}^{*}\right)}{\partial n}=-\frac{\left(\tau_{A}-\tau_{B}\right)^{2}}{2 n^{2}}<0$ for $\tau_{A} \neq \tau_{B}$, we thus have $\underbrace{\frac{\partial \log \left(\frac{C_{B}^{u}}{\Pi_{B}}\right)}{\partial \widetilde{\tau}} \frac{\partial \widetilde{\tau}}{\partial \phi\left(\gamma_{A}^{*}\right)}}_{>0} \cdot \frac{\partial \phi\left(\gamma_{A}^{*}\right)}{\partial n}<0$. The Lemma is thus proven.

\section{E Proof of Lemma 3}

Taking the log of (14) and differentiating with respect to $\sigma^{2}$ and $\lambda$ we obtain

$$
\frac{\partial \log \left(\frac{C_{B}^{j}}{\Pi_{B}}\right)}{\partial \sigma^{2}}=\frac{\partial \log \left(\frac{C_{B}^{j}}{\Pi_{B}}\right)}{\partial \beta_{2}} \cdot \frac{\partial \beta_{2}}{\partial \sigma^{2}},
$$

and

$$
\frac{\partial \log \left(\frac{C_{B}^{j}}{\Pi_{B}}\right)}{\partial \lambda}=\frac{\partial \log \left(\frac{C_{B}^{j}}{\Pi_{B}}\right)}{\partial \beta_{2}} \cdot \frac{\partial \beta_{2}}{\partial \lambda}+\frac{1}{\beta_{2}} \frac{v}{\widetilde{\tau}+(r+\lambda) v}
$$

where

$\frac{\partial \log \left(\frac{C_{B}^{j}}{\Pi_{B}}\right)}{\partial \beta_{2}}=\underbrace{\left(-\frac{1}{m^{j}} \frac{\partial m^{j}}{\partial \beta_{2}}\right)}_{\geq 0}+\underbrace{\left\{-\frac{1}{\beta_{2}}\left[\log \left(1-\beta_{2}\right)+\frac{1}{\left(1-\beta_{2}\right)}\right]\right\}}_{>0}+\underbrace{\frac{1}{\beta_{2}^{2}} \log \left[\frac{\widetilde{\tau}}{\widetilde{\tau}+(r+\lambda) v}\right]}_{<0}$,

with $\frac{\partial \beta_{2}}{\partial \sigma^{2}}>0, \frac{\partial \beta_{2}}{\partial \lambda}<0$, and $\frac{\partial m^{u}}{\partial \beta_{2}}<\frac{\partial m^{p}}{\partial \beta_{2}}=0$. Given (35) we have $\frac{\partial \log \left(\frac{C_{B}}{\Pi_{B}}\right)}{\partial \beta_{2}}>0$

if $v$ is high enough. This is sufficient to obtain $\frac{\partial \log \left(\frac{C_{B}^{j}}{\Pi_{B}}\right)}{\partial \sigma^{2}}>0$ and $\frac{\partial \log \left(\frac{C_{B}^{j}}{\Pi_{B}}\right)}{\partial \lambda}<$ 0 .

As regards unprotected debt it is worth noting that the term $\left(-\frac{1}{m^{u}} \frac{\partial m^{u}}{\partial \beta_{2}}\right)$

is positive. Therefore we need a lower value of $v$ for the derivative $\frac{\partial \log \left(\frac{C_{B}^{u}}{\Pi_{B}}\right)}{\partial \beta_{2}}$ to be positive. This proves the Lemma. 


\section{F Derivation of (17) and (18)}

Let us compute the present value of the net loss of revenues due to income shifting from the parent company placed in A and its subsidiary operating in B. Given the current flow $\left(-\tau_{A} \gamma_{A}^{*} C_{B}^{j}\right)$, we can write its present value $a^{38}$

$N B_{B}^{j}\left(\Pi_{B}\right)= \begin{cases}0 & \text { after default } \\ -\left(\tau_{A} \gamma_{A}^{*} C_{B}^{j}\right) d t+e^{-r d t} \xi\left[N B_{B}^{j}\left(\Pi_{B}+d \Pi_{B}\right)\right] & \text { before default. }\end{cases}$

Applying Itô's Lemma to (36), one obtains

$$
r N B_{B}^{j}\left(\Pi_{B}\right)=-\tau_{A} \gamma_{A}^{*} C_{B}^{j}+\frac{\sigma^{2}}{2} \Pi_{B}^{2} N B_{B_{\Pi_{B} \Pi_{B}}^{j}}\left(\Pi_{B}\right),
$$

with $N B_{B_{\Pi_{B} \Pi_{B}}^{j}}\left(\Pi_{B}\right)=\frac{\partial^{2} N B_{B}^{j}\left(\Pi_{B}\right)}{\partial \Pi_{B}^{2}}$. In the absence of financial bubbles the closed-form solution of (37) is

$$
N B_{B}^{j}\left(\Pi_{B}\right)=-\frac{\tau_{A} \gamma_{A}^{*} C_{B}^{j}}{r}+N_{2}^{j} \Pi_{i}^{\beta_{i}}
$$

Let us next compute $N_{2}^{j}$. We know that when default occurs the net flow vanishes and, thus, the equality

$$
N B_{B}^{j}\left(\bar{\Pi}_{B}^{j}\right)=0
$$

holds. Substituting (38) into the condition (39) it is easy to obtain (17).

Following the same procedure we can compute the present value of the net loss of revenues due to profit shifting from the parent company placed in B and its subsidiary operating in A (18).

\section{G Proof of Proposition 1}

To prove Proposition 1 let us focus on the decision of the government A. Substituting (19) into (20) and differentiating the objective function with

\footnotetext{
${ }^{38}$ Remember that $N B_{B}^{j}\left(\Pi_{B}\right)$ is computed by the government, that by assumption does not aim to expropriate the foreign subsidiary.
} 
respect to $\tau_{A}$ yields the following f.o.c.

$$
\begin{gathered}
\frac{\partial W_{A}^{j}}{\partial \tau_{A}}=\frac{\partial \widetilde{\tau}}{\partial \tau_{A}} \frac{C_{B}^{j}}{r+\lambda}+\frac{\partial f^{j}\left(\bar{\Pi}_{B}^{j}\right)}{\partial \tau_{A}}-\gamma_{A}^{*} \frac{C_{B}^{j}}{r}\left[1-\left(\frac{\Pi_{B}}{\bar{\Pi}_{B}^{j}}\right)^{\beta_{2}}\right]+\gamma_{B}^{*} \frac{C_{A}^{j}}{r}\left[1-\left(\frac{\Pi_{A}}{\bar{\Pi}_{A}^{j}}\right)^{\beta_{2}}\right]+ \\
-\tau_{A} \frac{\partial \gamma_{*}}{\partial \tau_{A}} \frac{C_{B}^{j}}{r}\left[1-\left(\frac{\Pi_{B}}{\bar{\Pi}_{B}^{j}}\right)^{\beta_{2}}\right]-\tau_{A} \gamma_{A}^{*} \frac{1}{r} \frac{\partial C_{B}^{j}}{\partial \tau_{A}}\left[1-\left(\frac{\Pi_{B}}{\bar{\Pi}_{B}^{j}}\right)^{\beta_{2}}\right]+\tau_{A} \gamma_{A}^{*} \frac{C_{B}^{j}}{r}\left[\frac{\partial\left(\frac{\Pi_{B}}{\bar{\Pi}_{B}^{j}}\right)^{\beta_{2}}}{\partial \tau_{A}}\right]+ \\
+\tau_{A} \frac{\partial \gamma_{B}^{*}}{\partial \tau_{A}} \frac{C_{A}^{j}}{r}\left[1-\left(\frac{\Pi_{A}}{\bar{\Pi}_{A}^{j}}\right)^{\beta_{2}}\right]+\tau_{A} \gamma_{B}^{*} \frac{1}{r} \frac{\partial C_{A}^{j}}{\partial \tau_{A}}\left[1-\left(\frac{\Pi_{A}}{\bar{\Pi}_{A}^{j}}\right)^{\beta_{2}}\right]-\tau_{A} \gamma_{B}^{*} \frac{C_{A}^{j}}{r}\left[\frac{\partial\left(\frac{\Pi_{A}}{\bar{\Pi}_{A}^{j}}\right)^{\beta_{2}}}{\partial \tau_{A}}\right]+\frac{\Pi_{A}}{r}=0
\end{gathered}
$$

with $\gamma_{A}^{*}=\frac{\tau_{A}-\tau_{B}}{n}, \gamma_{B}^{*}=\frac{\tau_{B}-\tau_{A}}{n}, \frac{\partial \gamma_{A}^{*}}{\partial \tau_{A}}=\frac{1}{n}$, and $\frac{\partial \gamma_{B}^{*}}{\partial \tau_{A}}=-\frac{1}{n}$.

Under symmetry we have $\tau_{k}=\widetilde{\tau}=\tau,\left.\frac{\partial \widetilde{\tau}}{\partial \tau_{k}}\right|_{\tau_{A}=\tau_{B}}=\gamma_{k}^{*}=0, \Pi_{k}=\Pi$, $C_{k}^{j}=C^{j}$, and $\bar{\Pi}_{k}^{j}=\bar{\Pi}^{j}=m^{j} C_{k}^{j}$, with $k=A, B$, and $j=p$, u. The f.o.c. (40) thus reduces to

$$
\left.\frac{\partial W_{A}^{j}}{\partial \tau_{A}}\right|_{\tau_{A}=\tau_{B}}=\left.\frac{\partial f^{j}\left(\bar{\Pi}_{B}^{j}\right)}{\partial \tau_{A}}\right|_{\tau_{A}=\tau_{B}}-\tau \frac{2}{n} \frac{C^{j}}{r}\left[1-\left(\frac{\Pi}{\bar{\Pi}^{j}}\right)^{\beta_{2}}\right]+\frac{\Pi}{r}=0 .
$$

\section{G.1 Protected debt}

If debt is protected we have $\left.\frac{\partial f^{p}\left(\bar{\Pi}_{B}^{p}\right)}{\partial \tau_{A}}\right|_{\tau_{A}=\tau_{B}}=f^{p}\left(\bar{\Pi}_{B}^{p}\right)=0$, and equation (41) reduces to

$$
\frac{\partial W_{A}^{p}}{\partial \tau_{A}}=-\tau \frac{2}{n} \frac{C^{p}}{r}\left[1-\left(\frac{\Pi}{\bar{\Pi}^{p}}\right)^{\beta_{2}}\right]+\frac{\Pi}{r}=0
$$

Given $m^{p}=1$ and $C^{p}=\Pi$, substituting (14) into (42) we have

$1=R^{p}(\tau) \equiv \frac{2}{n}\left(\frac{1}{1-\beta_{2}}\right)^{1-\frac{1}{\beta_{2}}}\left[\frac{\tau}{\tau+(r+\lambda) v}\right]^{1-\frac{1}{\beta_{2}}}\left[\left(1-\beta_{2}\right)(r+\lambda) v-\beta_{2} \tau\right]$.

Let us analyze the RHS of (43). It is easy to ascertain that $R^{p}(0)=0$, $\frac{\partial R^{p}(\tau)}{\partial \tau}>0$ for $\tau \geq 0$, and $\lim _{\tau \rightarrow \infty} R^{p}(\tau)=\infty$. As shown in Fig. 4 therefore there exists one point $\tau^{*}$ such that the equality (43) holds. If $n$ is high enough we have $\tau^{*} \in(0,1]$. 


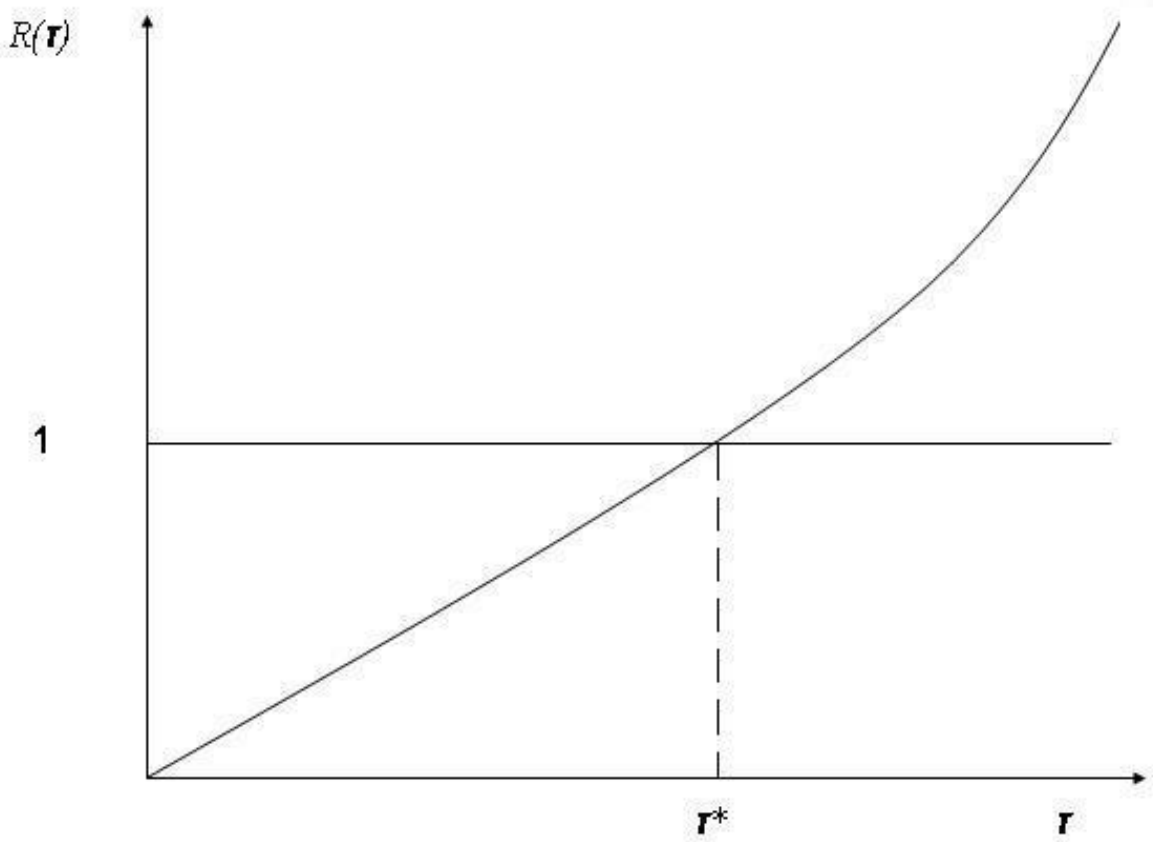

Figure 4: The equilibrium condition (43). 


\section{G.2 Unprotected debt}

If debt is unprotected equation (41) reduces to

$$
\left.\frac{\partial W_{A}^{u}}{\partial \tau_{A}}\right|_{\tau_{A}=\tau_{B}}=\left.\frac{\partial f^{u}\left(\bar{\Pi}_{B}^{u}\right)}{\partial \tau_{A}}\right|_{\tau_{A}=\tau_{B}}-\tau \frac{2}{n} \frac{C^{u}}{r}\left[1-\left(\frac{\Pi}{\bar{\Pi}^{u}}\right)^{\beta_{2}}\right]+\frac{\Pi}{r}=0 .
$$

Using (8) and (14) we thus have

$$
\frac{\partial f^{u}\left(\bar{\Pi}_{B}^{u}\right)}{\partial \tau_{A}}=\left[-\frac{1}{\beta_{2}} \frac{1-\tau_{B}}{r+\lambda}\left(\frac{1}{1-\beta_{2}}\right)^{1-\frac{1}{\beta_{2}}} \Pi\right] \frac{\partial\left[\left(\frac{\tau}{\tau+(r+\lambda) v}\right)^{1-\frac{1}{\beta_{2}}}\right]}{\partial \widetilde{\tau}} \frac{\partial \widetilde{\tau}}{\partial \tau_{A}} .
$$

Under symmetry we have $\frac{\partial \widetilde{\tau}}{\partial \tau_{A}}=0$, and hence $\left.\frac{\partial f^{u}\left(\bar{\Pi}_{B}^{u}\right)}{\partial \tau_{A}}\right|_{\tau_{A}=\tau_{B}}=0$. Therefore (44) reduces to

$$
\frac{\partial W_{A}}{\partial \tau_{A}}=-\tau \frac{2}{n} \frac{C^{u}}{r}\left[1-\left(\frac{\Pi}{\bar{\Pi}^{u}}\right)^{\beta_{2}}\right]+\frac{\Pi}{r}=0,
$$

with

$$
C^{u}=\frac{\beta_{2}-1}{\beta_{2}}\left[\frac{1}{1-\beta_{2}} \frac{\tau}{\tau+(r+\lambda) v}\right]^{-\frac{1}{\beta_{2}}} \Pi
$$

and

$$
\left(\frac{\Pi}{\bar{\Pi}^{u}}\right)^{\beta_{2}}=\frac{1}{1-\beta_{2}} \frac{\tau}{\tau+(r+\lambda) v} .
$$

Using (45) we thus obtain

$$
1=R^{u}(\tau) \equiv\left(\frac{\beta_{2}-1}{\beta_{2}}\right) R^{p}(\tau)
$$

It is thus easy to ascertain that $R^{u}(0)=0, \frac{\partial R^{u}(\tau)}{\partial \tau}>0$ for $\tau \geq 0$, and $\lim _{\tau \rightarrow \infty} R^{u}(\tau)=\infty$. Moreover we know from (46) that $R^{u}(\tau)>R^{p}(\tau)$. This entails that the equality $R^{u}(\tau)=1$ holds for a lower value of $\tau$. As a consequence, the equilibrium tax rate is lower under unprotected debt financing. This concludes the proof. 


\section{H Proof of Corollary 1}

To prove Corollary 1 let us add the value of debt (i.e. (7)) to the objective function (19), so as to obtain the new objective function of government $\mathrm{A}^{39}$

$$
\begin{gathered}
£_{A}^{j}=\frac{\Psi_{A}}{r}+\frac{\left(1-\tau_{B}\right) \Pi_{B}+\widetilde{\tau} C_{B}^{j}}{r+\lambda}-\left(\frac{\widetilde{\tau}}{r+\lambda}+v\right) C_{B}^{j}\left(\frac{\Pi_{B}}{\overline{\bar{\Pi}}_{B}^{j}}\right)^{\beta_{2}}+ \\
-\tau_{A} \gamma_{A}^{*} \frac{C_{B}^{j}}{r}\left[1-\left(\frac{\Pi}{\bar{\Pi}_{B}^{j}}\right)^{\beta_{2}}\right]+\tau_{A} \gamma_{B}^{*} \frac{C_{A}^{j}}{r}\left[1-\left(\frac{\Pi_{A}}{\overline{\bar{\Pi}}_{A}^{j}}\right)^{\beta_{2}}\right]+\tau_{A} \frac{\Pi_{A}}{r} .
\end{gathered}
$$

Differentiating (47) with respect to $\tau_{A}$ we have

$$
\begin{gathered}
\frac{\partial £_{A}^{j}}{\partial \tau_{A}}=\frac{\partial \widetilde{\tau}}{\partial \tau_{A}} \frac{C_{B}^{j}}{r+\lambda}-\frac{\partial \widetilde{\tau}}{\partial \tau_{A}} C_{B}^{j}\left(\frac{\Pi_{B}}{\bar{\Pi}_{B}^{j}}\right)^{\beta_{2}}-\left(\frac{\widetilde{\tau}}{r+\lambda}+v\right) \frac{\partial C_{B}^{j}}{\partial \tau_{A}}\left(\frac{\Pi_{B}}{\bar{\Pi}_{B}^{j}}\right)^{\beta_{2}}-\left(\frac{\widetilde{\tau}}{r+\lambda}+v\right) C_{B}^{j}\left[\frac{\partial\left(\frac{\Pi_{B}}{\bar{\Pi}_{B}^{j}}\right)^{\beta_{2}}}{\partial \tau_{A}}\right]+ \\
-\gamma_{A}^{*} \frac{C_{B}^{j}}{r}\left[1-\left(\frac{\Pi_{B}}{\overline{\bar{\Pi}}_{B}^{j}}\right)^{\beta_{2}}\right]+\gamma_{B}^{*} \frac{C_{A}^{j}}{r}\left[1-\left(\frac{\Pi_{A}}{\bar{\Pi}_{A}^{j}}\right)^{\beta_{2}}\right]+ \\
-\tau_{A} \frac{\partial \gamma_{A}^{*}}{\partial \tau_{A}} \frac{C_{B}^{j}}{r}\left[1-\left(\frac{\Pi_{B}}{\bar{\Pi}_{B}^{j}}\right)^{\beta_{2}}\right]-\tau_{A} \gamma_{A}^{*} \frac{1}{r} \frac{\partial C_{B}^{j}}{\partial \tau_{A}}\left[1-\left(\frac{\Pi_{B}}{\bar{\Pi}_{B}^{j}}\right)^{\beta_{2}}\right]+\tau_{A} \gamma_{A}^{*} \frac{C_{B}^{j}}{r}\left[\frac{\partial\left(\frac{\Pi_{B}}{\bar{\Pi}_{B}^{j}}\right)^{\beta_{2}}}{\partial \tau_{A}}\right]+ \\
+\tau_{A} \frac{\partial \gamma_{B}^{*}}{\partial \tau_{A}} \frac{C_{A}^{j}}{r}\left[1-\left(\frac{\Pi_{A}}{\bar{\Pi}_{A}^{j}}\right)^{\beta_{2}}\right]+\tau_{A} \gamma_{B}^{*} \frac{1}{r} \frac{\partial C_{A}^{j}}{\partial \tau_{A}}\left[1-\left(\frac{\Pi_{A}}{\bar{\Pi}_{A}^{j}}\right)^{\beta_{2}}\right]-\tau_{A} \gamma_{B}^{*} \frac{C_{A}^{j}}{r}\left[\frac{\partial\left(\frac{\Pi_{A}}{\overline{\bar{\Pi}}_{A}^{j}}\right)^{\beta_{2}}}{\partial \tau_{A}}\right]+\frac{\Pi_{A}}{r}=0,
\end{gathered}
$$

where $\frac{\partial C_{B}^{j}}{\partial \tau_{A}}=\frac{\partial C_{B}^{j}}{\partial \widetilde{\tau}} \frac{\partial \widetilde{\tau}}{\partial \tau_{A}}$, and $\frac{\partial\left(\frac{\Pi_{B}}{\bar{\Pi}_{B}^{j}}\right)^{\beta_{2}}}{\partial \tau_{A}}=\frac{\partial\left(\frac{\Pi_{B}}{\bar{\Pi}_{B}^{j}}\right)^{\beta_{2}}}{\partial \widetilde{\tau}} \frac{\partial \widetilde{\tau}}{\partial \tau_{A}}$, with $\frac{\partial \widetilde{\tau}}{\partial \tau_{A}}=\frac{\left(\tau_{A}-\tau_{B}\right)}{n}$.

Under symmetry we have $\frac{\partial \widetilde{\tau}}{\partial \tau_{A}}=0,\left.\frac{\partial C_{B}^{j}}{\partial \tau_{A}}\right|_{\tau_{A}=\tau_{B}}=0$, and $\frac{\partial\left(\frac{\Pi_{B}}{\bar{\Pi}_{B}^{j}}\right)^{\beta_{2}}}{\partial \tau_{A}}=0$. Thus (48) reduces to

$$
\left.\frac{\partial £_{A}^{j}}{\partial \tau_{A}}\right|_{\tau_{A}=\tau_{B}}=-\tau \frac{2}{n} \frac{C^{j}}{r}\left[1-\left(\frac{\Pi}{\bar{\Pi}^{j}}\right)^{\beta_{2}}\right]+\frac{\Pi}{r}=0
$$

\footnotetext{
${ }^{39}$ Following the same procedure it is straightforward to obtain the objective function of government $\mathrm{B}$.
} 
As can be seen eq. (49) collapses to (41). This is sufficient to prove that the equilibrium tax rate is the same as that obtained in Proposition 1 . The Corollary is thus proven.

\section{Proof of Proposition 2}

To prove Proposition 2 let us recall (43). It is easy to show that $\frac{\partial R(\tau)}{\partial v}<0$, and $\frac{\partial R(\tau)}{\partial n}<0$. This effect is depicted in Fig. 5. As can be seen, an increase in either $v$ or $n$ shifts curve $R(\tau)$ downwards.

Therefore the equilibrium tax rate increases from $\tau_{0}^{*}$ to $\tau_{1}^{*}$.

A similar result can be obtained under unprotected debt financing. According to Proposition 1, however, the equilibrium tax rate is lower than that obtained in the protected-debt case. This concludes the proof. 


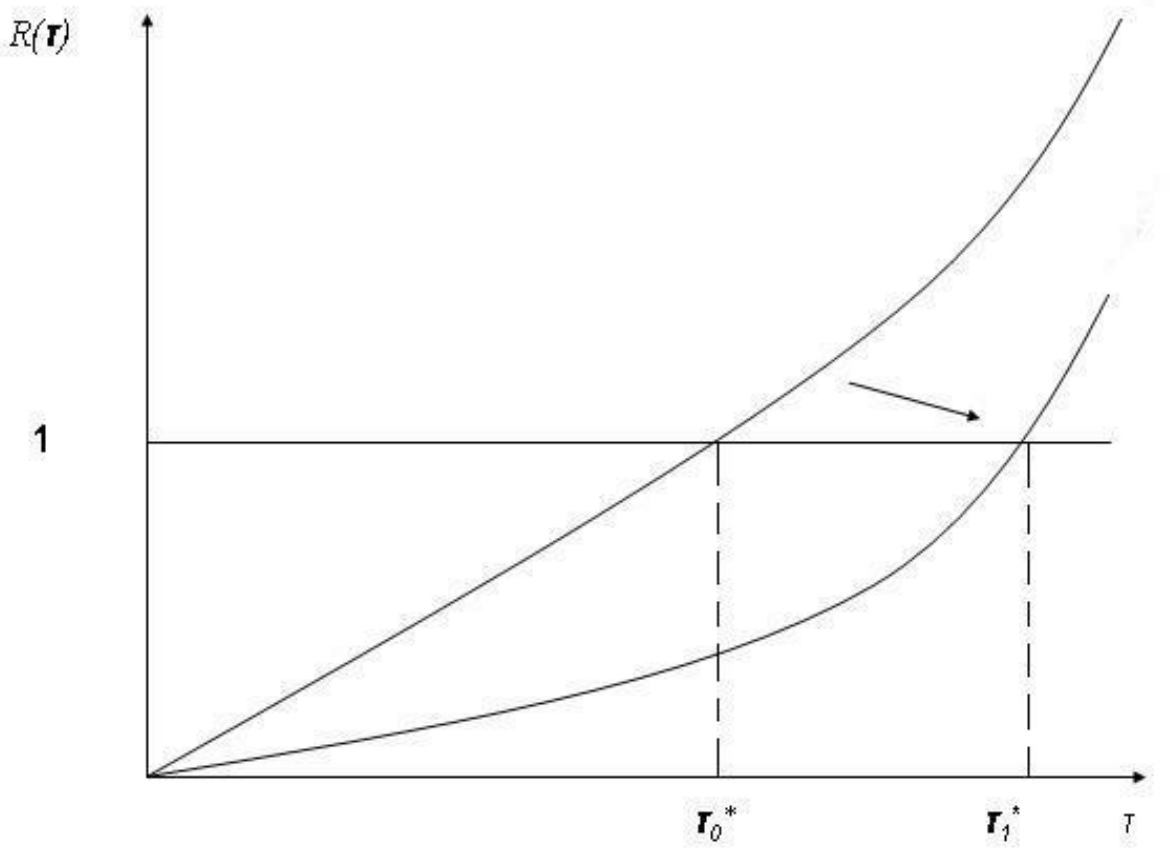

Figure 5: The effect of an increase in $n$ and/or $v$ on the equilibrium tax rate $\tau^{*}$. 


\section{References}

[1] Altshuler, R. and H. Grubert (2003), Repatriation Taxes, Repatriation Strategies and Multinational Financial Policy, Journal of Public Economics, 87, pp. 73-107.

[2] Branch, B. (2002), The Costs of Bankruptcy: A Review, International Review of Financial Analysis, 11, pp. 39-57.

[3] Cherian, J.A. and E. Perotti (2001), Option Pricing and Foreign Investment under Political Risk, Journal of International Economics, 55, pp. 359-377.

[4] Desai, M.A. (2003), The Divergence between Book Income and Tax Income, Tax Policy and the Economy, 17, pp. 169-206, Cambridge: MIT Press for the National Bureau of Economic Research.

[5] Desai, M.A. (2005), The Degradation of Reported Corporate Profits, Journal of Economic Perspectives, 12, pp. 171-192.

[6] Desai, M.A. and F.C. Foley (2004), The Comovement of Returns and Investment within the Multinational Firm, NEBR Working paper series No. 10785.

[7] Desai, M.A., F.C. Foley, and J.R. Jr. Hines (2004), A Multinational Perspective on Capital Structure Choice and Internal Capital Markets, Journal of Finance, 59, pp. 2451-87.

[8] Devereux, M.P., B. Lockwood, and M. Redoano (2004), Do Countries Compete over Corporate Tax Rates?, University of Warwick.

[9] Dixit, A. and R.S. Pindyck (1994), Investment under Uncertainty, Princeton University Press.

[10] Fan, J.P.H., S. Titman, and G.J. Twite (2003), An International Comparison of Capital Structure and Debt Maturity Choices, AFA 2005 Philadelphia Meetings, EFA 2003 Annual Conference Paper No. 769.

[11] Fuest, C. and T. Hemmelgarn (2005), Corporate Tax Policy, Foreign Firm Ownership and Thin Capitalization, Regional Science and Urban Economics, 35, pp. 508-526. 
[12] Goldstein, R., N. Ju and H. Leland (2001), An EBIT-Based Model of Dynamic Capital Structure, Journal of Business, 74, pp. 483-512.

[13] Gordon, R.H. and H.R. Varian (1989), Taxation of Asset Income in the Presence of a World Securities Market, Journal of International Economics, 26, pp. 205-226.

[14] Graham, J.R. and A.L. Tucker (2005), Tax Shelters and Corporate Debt Policy, Available at SSRN: http://ssrn.com/abstract $=633042$.

[15] Haufler, A. and G. Schjelderup (2000), Corporate Tax Systems and Cross Country Profit Shifting, Oxford Economic Papers, 52, pp. 306325 .

[16] Hines, J.R. (1999), Lessons from Behavioral Responses to International Taxation, National Tax Journal, 52, pp. 304-322.

[17] Keen, M. (1993), The Welfare Economics of Tax Co-ordination in the European Community: A Survey. Fiscal Studies 14, pp. 15-36.

[18] La Porta F., F. Lopez-De-Silanes, A. Shleifer, and R.W. Vishny (1997), Legal Determinants of External Finance, Journal of Finance, 52, pp. 1131-1150.

[19] Lee, K. (2004), Taxation of Mobile Factors as Insurance under Uncertainty, Scandinavian Journal of Economics, 106, pp. 253-271.

[20] Leland, H.E. (1994), Corporate Debt Value, Bond Covenants, and Optimal Capital Structure, Journal of Finance, 49, pp. 1213-1252.

[21] McDonald, R. and D. Siegel (1985), Investment and the Valuation of Firms When There Is an Option to Shut Down, International Economic Review, 26, pp. 331-349.

[22] Mills, L.F. and K.J. Newberry (2004), Do Foreign Multinational's Tax Incentives Influence Their U.S. Income Reporting and Debt Policy?, National Tax Journal, 57, pp.89-107.

[23] Mintz, J. (2000), Reforming the Tax Cut Agenda, Canadian Tax Journal, 48, pp. 689-709. 
[24] Mintz, J. and M. Smart (2004), Income Shifting, Investment, and Tax Competition: Theory and Evidence from Provincial Taxation in Canada, Journal of Public Economics, 88, pp.1149-1168.

[25] Mintz, J. and A.J. Weichenrieder (2005), Taxation and the Financial Structure of German Outbound FDI, CESifo Working Paper No. 1612.

[26] Myers, S.C. (1977), Determinants of Corporate Borrowing, Journal of Financial Economics, 5, pp. 147-175.

[27] Panteghini, P.M. (2004), Neutrality Properties of Firm Taxation under Default Risk, Economics Bulletin, 8, N.4, pp.1-7.

[28] Panteghini, P.M. (2006), S-Based Taxation under Default Risk, Journal of Public Economics, forthcoming.

[29] Panteghini, P.M. and G. Schjelderup (2006), To Invest or not to Invest: A Real Options Approach to FDIs and Tax Competition, International Tax and Public Finance, forthcoming.

[30] Smith, C.W. Jr. and J.B. Warner (1977), Bankruptcy, Secured Debt, and Optimal Capital Structure: Comment, Journal of Finance, 34, pp. 247-51.

[31] Sørensen, B.E., Y. Wu and O. Yosha (2005), Home Bias and International Risk Sharing: Twin Puzzles Separated at Birth, CEPR Discussion Paper No. 5113.

[32] Wilson, J.D. and D.E. Wildasin (2004), Capital Tax Competition: Bane or Boon?, Journal of Public Economics, 88, pp. 1065-1091. 


\title{
CESifo Working Paper Series
}

\author{
(for full list see www.cesifo-group.de)
}

1657 Daniel Haile, Abdolkarim Sadrieh and Harrie A. A. Verbon, Cross-Racial Envy and Underinvestment in South Africa, February 2006

1658 Frode Meland and Odd Rune Straume, Outsourcing in Contests, February 2006

1659 M. Hashem Pesaran and Ron Smith, Macroeconometric Modelling with a Global Perspective, February 2006

1660 Alexander F. Wagner and Friedrich Schneider, Satisfaction with Democracy and the Environment in Western Europe - a Panel Analysis, February 2006

1661 Ben J. Heijdra and Jenny E. Ligthart, Fiscal Policy, Monopolistic Competition, and Finite Lives, February 2006

1662 Ludger Woessmann, Public-Private Partnership and Schooling Outcomes across Countries, February 2006

1663 Topi Miettinen and Panu Poutvaara, Political Parties and Network Formation, February 2006

1664 Alessandro Cigno and Annalisa Luporini, Optimal Policy Towards Families with Different Amounts of Social Capital, in the Presence of Asymmetric Information and Stochastic Fertility, February 2006

1665 Samuel Muehlemann and Stefan C. Wolter, Regional Effects on Employer Provided Training: Evidence from Apprenticeship Training in Switzerland, February 2006

1666 Laszlo Goerke, Bureaucratic Corruption and Profit Tax Evasion, February 2006

1667 Ivo J. M. Arnold and Jan J. G. Lemmen, Inflation Expectations and Inflation Uncertainty in the Eurozone: Evidence from Survey Data, February 2006

1668 Hans Gersbach and Hans Haller, Voice and Bargaining Power, February 2006

1669 Françoise Forges and Frédéric Koessler, Long Persuasion Games, February 2006

1670 Florian Englmaier and Markus Reisinger, Information, Coordination, and the Industrialization of Countries, February 2006

1671 Hendrik Hakenes and Andreas Irmen, Something out of Nothing? Neoclassical Growth and the 'Trivial' Steady State, February 2006

1672 Torsten Persson and Guido Tabellini, Democracy and Development: The Devil in the Details, February 2006 
1673 Michael Rauber and Heinrich W. Ursprung, Evaluation of Researchers: A Life Cycle Analysis of German Academic Economists, February 2006

1674 Ernesto Reuben and Frans van Winden, Reciprocity and Emotions when Reciprocators Know each other, February 2006

1675 Assar Lindbeck and Mats Persson, A Model of Income Insurance and Social Norms, February 2006

1676 Horst Raff, Michael Ryan and Frank Staehler, Asset Ownership and Foreign-Market Entry, February 2006

1677 Miguel Portela, Rob Alessie and Coen Teulings, Measurement Error in Education and Growth Regressions, February 2006

1678 Andreas Haufler, Alexander Klemm and Guttorm Schjelderup, Globalisation and the Mix of Wage and Profit Taxes, February 2006

1679 Kurt R. Brekke and Lars Sørgard, Public versus Private Health Care in a National Health Service, March 2006

1680 Dominik Grafenhofer, Christian Jaag, Christian Keuschnigg and Mirela Keuschnigg, Probabilistic Aging, March 2006

1681 Wladimir Raymond, Pierre Mohnen, Franz Palm and Sybrand Schim van der Loeff, Persistence of Innovation in Dutch Manufacturing: Is it Spurious?, March 2006

1682 Andrea Colciago, V. Anton Muscatelli, Tiziano Ropele and Patrizio Tirelli, The Role of Fiscal Policy in a Monetary Union: Are National Automatic Stabilizers Effective?, March 2006

1683 Mario Jametti and Thomas von Ungern-Sternberg, Risk Selection in Natural Disaster Insurance - the Case of France, March 2006

1684 Ken Sennewald and Klaus Waelde, “Itô's Lemma“ and the Bellman Equation for Poisson Processes: An Applied View, March 2006

1685 Ernesto Reuben and Frans van Winden, Negative Reciprocity and the Interaction of Emotions and Fairness Norms, March 2006

1686 Françoise Forges, The Ex Ante Incentive Compatible Core in Exchange Economies with and without Indivisibilities, March 2006

1687 Assar Lindbeck, Mårten Palme and Mats Persson, Job Security and Work Absence: Evidence from a Natural Experiment, March 2006

1688 Sebastian Buhai and Coen Teulings, Tenure Profiles and Efficient Separation in a Stochastic Productivity Model, March 2006 
1689 Gebhard Kirchgaessner and Silika Prohl, Sustainability of Swiss Fiscal Policy, March 2006

1690 A. Lans Bovenberg and Peter Birch Sørensen, Optimal Taxation and Social Insurance in a Lifetime Perspective, March 2006

1691 Moritz Schularick and Thomas M. Steger, Does Financial Integration Spur Economic Growth? New Evidence from the First Era of Financial Globalization, March 2006

1692 Burkhard Heer and Alfred Maussner, Business Cycle Dynamics of a New Keynesian Overlapping Generations Model with Progressive Income Taxation, March 2006

1693 Jarko Fidrmuc and Iikka Korhonen, Meta-Analysis of the Business Cycle Correlation between the Euro Area and the CEECs, March 2006

1694 Steffen Henzel and Timo Wollmershaeuser, The New Keynesian Phillips Curve and the Role of Expectations: Evidence from the Ifo World Economic Survey, March 2006

1695 Yin-Wong Cheung, An Empirical Model of Daily Highs and Lows, March 2006

1696 Scott Alan Carson, African-American and White Living Standards in the $19^{\text {th }}$ Century American South: A Biological Comparison, March 2006

1697 Helge Berger, Optimal Central Bank Design: Benchmarks for the ECB, March 2006

1698 Vjollca Sadiraj, Jan Tuinstra and Frans van Winden, On the Size of the Winning Set in the Presence of Interest Groups, April 2006

1699 Martin Gassebner, Michael Lamla and Jan-Egbert Sturm, Economic, Demographic and Political Determinants of Pollution Reassessed: A Sensitivity Analysis, April 2006

1700 Louis N. Christofides and Amy Chen Peng, Major Provisions of Labour Contracts and their Theoretical Coherence, April 2006

1701 Christian Groth, Karl-Josef Koch and Thomas M. Steger, Rethinking the Concept of Long-Run Economic Growth, April 2006

1702 Dirk Schindler and Guttorm Schjelderup, Company Tax Reform in Europe and its Effect on Collusive Behavior, April 2006

1703 Françoise Forges and Enrico Minelli, Afriat's Theorem for General Budget Sets, April 2006

1704 M. Hashem Pesaran, Ron P. Smith, Takashi Yamagata and Liudmyla Hvozdyk, Pairwise Tests of Purchasing Power Parity Using Aggregate and Disaggregate Price Measures, April 2006

1705 Piero Gottardi and Felix Kubler, Social Security and Risk Sharing, April 2006 
1706 Giacomo Corneo and Christina M. Fong, What's the Monetary Value of Distributive Justice?, April 2006

1707 Andreas Knabe, Ronnie Schoeb and Joachim Weimann, Marginal Employment Subsidization: A New Concept and a Reappraisal, April 2006

1708 Hans-Werner Sinn, The Pathological Export Boom and the Bazaar Effect - How to Solve the German Puzzle, April 2006

1709 Helge Berger and Stephan Danninger, The Employment Effects of Labor and Product Markets Deregulation and their Implications for Structural Reform, May 2006

1710 Michael Ehrmann and Marcel Fratzscher, Global Financial Transmission of Monetary Policy Shocks, May 2006

1711 Carsten Eckel and Hartmut Egger, Wage Bargaining and Multinational Firms in General Equilibrium, May 2006

1712 Mathias Hoffmann, Proprietary Income, Entrepreneurial Risk, and the Predictability of U.S. Stock Returns, May 2006

1713 Marc-Andreas Muendler and Sascha O. Becker, Margins of Multinational Labor Substitution, May 2006

1714 Surajeet Chakravarty and W. Bentley MacLeod, Construction Contracts (or "How to Get the Right Building at the Right Price?”), May 2006

1715 David Encaoua and Yassine Lefouili, Choosing Intellectual Protection: Imitation, Patent Strength and Licensing, May 2006

1716 Chris van Klaveren, Bernard van Praag and Henriette Maassen van den Brink, Empirical Estimation Results of a Collective Household Time Allocation Model, May 2006

1717 Paul De Grauwe and Agnieszka Markiewicz, Learning to Forecast the Exchange Rate: Two Competing Approaches, May 2006

1718 Sijbren Cnossen, Tobacco Taxation in the European Union, May 2006

1719 Marcel Gérard and Fernando Ruiz, Interjurisdictional Competition for Higher Education and Firms, May 2006

1720 Ronald McKinnon and Gunther Schnabl, China's Exchange Rate and International Adjustment in Wages, Prices, and Interest Rates: Japan Déjà Vu?, May 2006

1721 Paolo M. Panteghini, The Capital Structure of Multinational Companies under Tax Competition, May 2006 